\title{
KÉTNYELVI PEDAGÓGUSKÉPZÉSBEN RÉSZT VEVŐ HALLGATÓK NÉZETEINEK MEGJELENÉSE KREATÍV VIZUÁLIS ALKOTÁSAIKBAN ${ }^{1}$
}

\section{Trentinné Benkő Éva}

Eötvös Loránd Tudományegyetem

\section{A kutatás háttere és indokoltsága}

A magyar közoktatásban - a folyamatosan zajló szakmai, oktatáspolitikai és társadalmi viták mellett - az elmúlt évtizedben is tovább emelkedett a kétnyelvü óvodai és általános iskolai programok száma (Kovács-Molnárné, 2003; Kovács, 2006, 2009; Morvai-Poór, 2006; Vámos-Kovács, 2008; Tárnok, 2009; Tolnai, 2009; Kovács-Trentinné, 2010). Ezáltal jelentősen megnőtt a kereslet a kétnyelvü fejlesztési feladatok színvonalas ellátására alkalmas, speciális szaktudású és szakképzettségü pedagógusok iránt. Ugyanakkor, a kétnyelvi ${ }^{2}$ pedagógusképzés egyelöre még két szempontból lemaradásban van a közoktatás igényeihez képest: 1. nincs bevizsgált felsőoktatási gyakorlat a kétnyelvü programokban részt vállaló pedagógusok képzésére és továbbképzésére és 2. Magyarországon csak elenyésző számú felsőoktatási intézményben van speciális korai kétnyelvi (nem nemzetiségi) program az alapképzés szintjén. Ez utóbbiak közül az egyik az ELTE Tanító- és Óvóképző Kara (Kovács, 2009, Demeter-Szarka, 2011).

A hallgatói nézetek a kétnyelvi pedagógus szerepére, feladataira, a korai kétnyelvü fejlesztés céljára és módszereire vonatkozóan kiemelten meghatározóak az eredményesség szempontjából. A kétnyelvü programokban tanító-nevelő pedagógusok kompetenciái (lásd tág értelmezés, Falus, 2006, Vass, 2006a,b) rendkívül sokrétüek és sok tekintetben speciálisak. Magukba foglalják az egynyelvü pedagógusi kompetenciákat, kiegészítve azokat a kétnyelvü kontextus szempontjából speciális ismeretekkel és képességekkel; többek között célnyelvi, szaknyelvi, nyelvpedagógiai, szakmódszertani, interkulturális és IKT-s területeken. Elengedhetetlen továbbá a két-, illetve többnyelvüséggel, a kisgyermekek holisztikus fejlesztésével, a reflektív gyakorlattal, valamint a saját élethosszig tartó fejlődéssel kapcsolatos megfelelő attitűdök megléte is. A kutatást indokolja, hogy eddig még nem történt meg a korai kétnyelvi pedagógusképzésben részt vevő jelöltek nézeteinek (beliefs) feltárása leendő feladatukról és a képzésről. A hallgatói vélekedések, szubjektív elméletek alapvetően meghatározzák a felsőoktatási tanulmányok hatékonyságát, a pályaszocializációs és a majdani pályaviteli folyamatok sikerét. A vizsgálat így egyszerre szolgál kutatási és képzési célokat.

\footnotetext{
${ }^{1}$ A teljes kutatás részletei a témában készülő doktori értekezésből ismerhetők meg. ELTE PPK Neveléstudományi Doktori Iskola, Témavezető: Vámos Ágnes egyetemi tanár.

${ }^{2}$ A tanulmányban Poór Zoltán (2012) javaslatára eltérő jelentésben/értelmezésben használom a kétnyelvü és kétnyelvi terminusokat. Elöbbit a két nyelven (anya- és célnyelven) zajló fejlesztésre, a kétnyelvü óvodai, iskolai kontextusra; míg utóbbit a kétnyelvü programokban résztvevő, de nem okvetlenül kétnyelvű pedagógusokra, illetve a kétnyelvü fejlesztésre felkészítő (de nem két nyelven, hanem kizárólag idegen nyelven zajló) képzésre alkalmazom.
} 


\section{A kutatást alapozó szakirodalom}

A nézetek (beliefs) fogalmának meghatározása

A szakirodalom többféle tartalommal ruházza fel a nézeteket, attól függően, hogy egyes kutatók mennyire tekintik ezeket elméleti jellegüeknek és mennyire konkrét, képekben kifejeződő, szemléletes képződményeknek (Wubbels, 1992, Korthagen, 1993). A meghatározás további szempontjai közé tartozik, hogy hogyan különböztetik meg a nézeteket a hasonló konstrukcióktól: a tudástól és az attitüdöktől (Dudás, 2006). Egyes kutatók nem különítik el a tudást és a nézeteket: „a tudás magában foglal mindent, amit egy személy tud, vagy igaznak hisz, akár bizonyított valamely objektív, illetve külső formában, akár nem" (Alexander, Schaller és Hare, 1991. 317. Idézi Kimmel, 2007. 15). Azon szerzőknél, akik különbséget tesznek nézetek és tudás között, a nézetek általában vélekedést, elkötelezettséget, ideológiákat jelölnek, míg a tudáson inkább tényszerü, a szakszerü cselekvést irányító propozíciók értendök (Calderhead, 1996. 719.). A konstruktivista felfogás nem különíti el a kettőt (Glaserfeld, 1995; Nahalka, 1997; Mayer-Smith és Mitchell, 1997; Falus, 2001; Holt-Reynolds, 1992; Feketéné, 2002, idézi Kimmel, 2007). Szerintük a tudás is egyfajta szubjektív meggyőződés, személyes konstrukció eredménye, hasonlóan a nézetekhez, melyek olyan feltételezések, propozíciók a világról, amelyeket igazaknak vélünk (Richardson, 1996, 103).

A nézetek többnyire implicitek, rejtettek, kívül esnek a tudatosság határán, elemzés és reflektálás nélküli folyamatban jönnek létre. Ezek a szubjektív elméletek, amelyek egy adott területre, jelenségre vonatkozó értékek és eszmék integráns egységei, segítik az egyént saját személyisége és a világ megértésében (Polak, 1998. Idézi Falus, 2006, 30-31). Richardson (1996, 103) kiemeli azt is, hogy a nézetek olyan mentális konstrukciók, amelyek döntően befolyásolják ítéleteinket és mások megítélését is. Az attitüddel összehasonlítva egyes szerzők azt hangsúlyozzák, hogy a nézetek inkább kognitív, az attitüdök inkább affektív jellegű pszichikai képződmények (Kimmel, 2007, 15). Abban azonban megegyeznek, hogy mindkettő nehezen változtatható és döntően befolyásolják az egyén döntéseit és tetteit, hiszen szürőként, filterként, értelmezési lencseként müködnek (Richardson, 1996, 103; Falus, 2001, 23; Kimmel, 2007). Az eltérő magyarázatok és értelmezések közös jellemzője, hogy a nézeteket a kutatók mind tapasztalatokból, élményekből származó pszichikus konstrukcióknak tekintik (Dudás, 2007, 48).

A fogalom és jelenség komplexitását jelzi a szakirodalomban előforduló számos különböző elnevezés is. Az 1. számú táblázatban a külföldi szerzők által a nézetekre alkalmazott megnevezéseket gyüjtöttem össze. 
1. sz. táblázat: Példák a nézetek megnevezésére a külföldi szakirodalomban (Falus, 2006, 30-31; Dudás, 2007, 48-49; Kimmel, 2007, 11-45; Bárdossy és Dudás, 2011 alapján).

\begin{tabular}{|l|l|l|}
\hline Szakirodalmi elnevezések a nézetekre & Szerző & Évszám \\
\hline értékelő rendszer & Schon & 1983 \\
\hline gyakorlati tudás & $\begin{array}{l}\text { Elbaz } \\
\text { Schon, Shulman }\end{array}$ & 1983 \\
\hline személyes elméletek & Fox & \\
& Clark és Peterson & 1983 \\
& Griffith és Tann & 1986 \\
& Shulman & 1992 \\
\hline stratégiai tudás & Clandinin & 1986 \\
\hline a tanításra vonatkozó képzetek & Conelly és Clandinin & 1986 \\
\hline a tanár személyes gyakorlati elméletei, & Clandinin és Conelly & \\
személyes gyakorlati tudás & Polak & 1987 \\
\hline szubjektív elméletek & Goodman & 1988 \\
\hline intuitív ernyők, gyakorlati tanításfilozófia & Clark & 1988 \\
\hline implicit teóriák & Calderhead, Robson & 1988 \\
\hline imázsok & Bullough és mtsai & 1991 \\
\hline tanítási metaforák & & 1991, \\
& & 1992 \\
\hline nézetrendszerek & Kagan & 1994 \\
\hline ,álruhába öltöztetett nézetek” (lsd külön) & Pajares & 1992 \\
\hline implicit elméletek & Pajares & 1992 \\
\hline & Claxton & 1992 \\
\hline
\end{tabular}

A jelen kutatás szempontjából meghatározó tág értelmezés Pajares (1992) nevéhez füződik. Ö az előzetes tudást, nézeteket a következőképpen definiálja: „attitüdök, értékek, ítéletek, axiómák, vélemények, ideológiák, érzékelések, elképzelések, fogalmi rendszerek, előfeltevések, beállítottságok, implicit elméletek, explicit elméletek, személyes elméletek, belső mentális folyamatok, cselekvési stratégiák, a gyakorlat szabályai, gyakorlati elvek, perspektívák, a megértés repertoárjai, szociális stratégiák...” „álruhában és álnéven” mind nézetek („,beliefs”). (Pajares, 1992, 309, idézi Kimmel, 2007, 14.)

\section{A nézetek szerepe a pedagógusképzésben}

A pedagógusok, pedagógusjelöltek nézeteivel és azok változásaival számos tanulmány foglalkozik, itthon és külföldön egyaránt. A magyar kutatások - a teljesség igénye nélkül - a témát különböző aspektusokkal gazdagították: Golnhofer-M. Nádasi (1981); Hunyadyné (1993, 2001, 2004); Falus (1997, 2001, 2002, 2004); Hunyadyné-Ungárné (1999); Vámos (2001a,b, 2003a,b, 2008); M. Nádasi (2002, 2006); Szivák (2003); Nahalka (2003); Sántha (2004); Köcséné Szabó (2007); Dudás (2005, 2007); Kimmel (2007).

Abban a legtöbb szerző egyetért, hogy a ,pedagógusok rendelkeznek valamilyen, többé vagy kevésbé explicit, többé vagy kevésbé koherens nézetrendszerrel, amely segíti őket a bonyolult pedagógiai jelenségek 
strukturálásában, megértésében, s befolyásolja gyakorlati tevékenységüket", állítja Falus (2006, 31, 43), utalva Calderhead (1996), Polak (1998) és Richardson (1996) munkáira. A nézetek Pajares (1992, 324-325) szerint korán kialakulnak, nehezen változnak meg, értékelö természetük miatt szürővé válnak, melyen keresztül értelmezzük az új jelenségeket. Sajátos körülmény a pedagógusképzésben más felsőoktatási képzésekhez képest, hogy a hallgatók tanításról alkotott nézeteinek már vannak bizonyos tapasztalati alapjai, amikorra eljutnak a felsőoktatásba. Ez utóbbi jellegzetesség avval magyarázható, állítja Lortie (1975), hogy minden pedagógusjelölt megközelítőleg 10000 órányi tanulással-tanítással kapcsolatos saját tapasztalattal rendelkezik, mire bekerül a pedagógusképzésbe (vö. Falus, 2002). Lortie ,apprenticeship of observation”-nek, Hunyadyné $(2004,9)$ a „tanuló évek megfigyelései”-nek nevezi ezt a jelenséget.

Hunyadyné $(1993,165$.) arra hívja fel a figyelmet, hogy a hallgatók korábbi iskolai élményei „nem egyszerűen pályaválasztási motívumaik vagy a pályáról kialakított elképzeléseik forrását képezik, hanem meghatározzák reagálásukat egyes pedagógiai szituációkban, viselkedési sémaként múködnek a gyerekekkel való kapcsolatukban, értékelési és metodikai mintát adnak pedagógiai tevékenységükben". M. Nádasi kiemeli, hogy a pedagógusjelöltek saját kialakult, „hétköznapi pedagógiai elméleteik”-kel vesznek részt a didaktikai képzésben már a kezdetektől, és a pedagógusképzésen múlik, hogy a képzés végére - ha minden pozitív körülmény teljesül - a hallgatók nézetei átalakulnak-e ,egyéni, integrált pedagógiai elméletté" (2002, 211-212.). Hasonlóképpen fogalmaz Dudás is (2007, 50.), aki szerint a nézetek olyannyira értelmezési lencseként müködnek, hogy nagyban befolyásolhatják a képzés eredményességét, sőt egyesek szerint még azt is, hogy később hogyan fognak tanítani (Britzman, 1991; Calderhead, 1989, 1991, 1996; Calderhead és Robson, 1991; Falus, 1992; Johnston, 1992, 1994 és Pajares, 1992 munkáira hivatkozva). Bárdossy és Dudás (2011, 17.) szerint a nézetek feltárásának ,folyamata - a reflektív paradigma alapján - a személyiségen belül zajló változásnak, a gondolkodásban végbemenő részben percepciós, részben interpretációs folyamatnak tekinthető. Ez a folyamat önelemzést, a tapasztalatok reflexióját, az ehhez szükséges önelemző képességek müködését igényli és feltételezi."

Hunyadyné (1993, 2004), M. Nádasi (2002, 2006), Falus (2006), Dudás (2007) Bárdossy és Dudás (2011) mind azt emelik ki, hogy a pedagógusjelöltek szakmai fejlődésének egyik legfontosabb eleme az implicit nézetek, nézetrendszerek explicitté válása a laikus pedagógiai nézetek a képzés tartalmának megfelelő didaktika-elmélettel való élményszerü és meggyőző szembesítése során. A pedagógusképzés szempontjából a bemutatott hazai és külföldi szakirodalom alapján tehát az alábbi gondolatokat tartom döntőeknek a nézetek szempontjából összegzésként (2. sz. táblázat): 
2. sz. táblázat: A nézetek főbb jellemzői és a pedagógusképzéssel való összefüggései

\begin{tabular}{|c|c|}
\hline & \\
\hline - & a világról konstruált belső reprezentáció, kognitív struktúra \\
\hline & értelmezési keretként, szürőként müködik \\
\hline & sokszor rejtett és implicit \\
\hline & nehezen változtatható \\
\hline & $\begin{array}{l}\text { meghatározza, hogy a pedagógusjelölt hogyan értelmezi az új, korszerü ismereteket és } \\
\text { tapasztalatokat }\end{array}$ \\
\hline & $\begin{array}{l}\text { meghatározza, hogy a hallgató beépíti-e az új ismereteket a már meglévö mentális } \\
\text { modelljébe, azaz tanul-e az új információkból }\end{array}$ \\
\hline & agógusképzés célja és feladata (átfedésekkel): \\
\hline & $\begin{array}{l}\text { a jelöltek szűrőként viselkedő laikus pedagógiai nézeteinek összhangba hozása a } \\
\text { korszerú ismeretekkel }\end{array}$ \\
\hline & a rejtett, implicit nézetek feltárása, felhasználása, ha szükséges megváltoztatása \\
\hline$\bullet$ & új, korszerű ismeret, személyes megtapasztalás, élmény nyújtása a jelölteknek \\
\hline & annak elösegítése, hogy a jelölt érzékelje a sajátjától eltérő valóságkonstrukciót \\
\hline & $\begin{array}{l}\text { kognitív disszonancia létrehozása, ami motiválja a jelölt belső modellje átszervezésének } \\
\text { folyamatát, a tanulást }\end{array}$ \\
\hline & $\begin{array}{l}\text { konceptuális váltás elöidézése a jelöltek nézetrendszerében, annak elérése, hogy a jelölt } \\
\text { az új ismereteknek, tapasztalatoknak megfelelően átalakítsa már meglévő mentális } \\
\text { modelljét }\end{array}$ \\
\hline
\end{tabular}

\section{A nézetek feltárására alkalmas kvalitativ módszerek}

A nem mindig fogalmi szinten lévő, rejtett nézetek feltárására, tudatosítására alkalmas módszerek közé sorolhatók a hagyományos feltáró módszerek közül a megfigyelés, az interjú, a kérdőív. A nézetek kutatása ugyanakkor sajátos megközelítést, újfajta metodikát kívánt, így kifejlődtek a pedagógiai gondolkodás mélyebb megismerését, megértését segítő „új generációs” kutatási módszerek és technikák. Ilyenek többek között a fogalmi térkép, a szereprepertoár-rács és a metafora, melyek különösen alkalmasaknak bizonyultak az implicit nézetek explicitté változtatására. Többek között ezen kvalitatív kutatási módszerek és technikák alkalmazásáról számol be részletesen Szabolcs (1999, 2001), Szivák (2002, 2003), Ehmann (2002), Seidman (2002) és Vámos (2001, 2003, 2008). Falus (1998, 2001, 2002, 2007), Hunyadyné (2001, 2004, 2006), M. Nádasi (1999, 2001, 2002, 2006) és Dudás $(2005,2007)$ több publikációban is részletesen tárja fel és összegzi a pedagógusok, pedagógusjelöltek nézeteivel és azok változásával kapcsolatos hazai és külföldi kutatásokat. A nézetek feltárására alkalmas módszerek és technikák széles spektrumának illusztrálására szolgál a megnevezett szakirodalom alapján összeállított 3. sz. táblázat. 
3. sz. táblázat: Példák a nézetekkel kapcsolatos empirikus kutatásokra a publikációk időrendjében

\begin{tabular}{|c|c|c|}
\hline Az empirikus kutatás témája & Kutatási módszerek és technikák & $\begin{array}{l}\text { Szerzők és a } \\
\text { publikáció } \\
\text { időpontja }\end{array}$ \\
\hline $\begin{array}{l}\text { tanárjelöltek elgondolásai, } \\
\text { nézetei a nevelés céljáról }\end{array}$ & kérdőív & $\begin{array}{l}\text { Golnhofer-M. } \\
\text { Nádasi, } 1981\end{array}$ \\
\hline tanári döntéshozatal & támogatott felidézés & Falus, 1985 \\
\hline tanítási tervektől való eltérés & támogatott felidézés & Kotschy, 1985 \\
\hline $\begin{array}{l}\text { nézetek és gyakorlat kölcsönös } \\
\text { egymásra hatása }\end{array}$ & $\begin{array}{l}\text { mélyinterjúk, tanárokkal, diákokkal } \\
\text { folytatott viták és megbeszélések }\end{array}$ & $\begin{array}{l}\text { Richardson-Anders- } \\
\text { Tidwell-Lloyd, 1991, } \\
\text { idézi Richardson, } \\
1996\end{array}$ \\
\hline $\begin{array}{l}\text { „jó tanárral” kapcsolatos } \\
\text { vélekedések }\end{array}$ & $\begin{array}{l}\text { Kelly által kifejlesztett, a kérdöív és } \\
\text { az interjú sajátos ötvözete: } \\
\text { szereprepertortár-rács }\end{array}$ & Corporal, 1991 \\
\hline pedagógusok rivalizációja & mélyinterjú & Fülöp, 1993 \\
\hline $\begin{array}{l}\text { hallgatói nézetek és szakmai } \\
\text { fejlődés }\end{array}$ & $\begin{array}{l}\text { szövegelemzés: hallgatói írások, } \\
\text { naplók és portfóliók }\end{array}$ & Bullough, 1993 \\
\hline $\begin{array}{l}\text { nézetek a jó osztályvezetésről és } \\
\text { a tanár ellenőrző munkájáról }\end{array}$ & kérdőív & Johnson, 1994 \\
\hline nézetek & fogalomtérkép és rendezett fa & E. Szabó, 1996 \\
\hline $\begin{array}{l}\text { nézetek változásai (tanítási } \\
\text { gyakorlat előtt és után) }\end{array}$ & kérdőív & Nettle, 1998 \\
\hline $\begin{array}{l}\text { tanárjelöltek motivációval } \\
\text { kapcsolatos nézetei }\end{array}$ & $\begin{array}{l}\text { szöveg (motivációról) reflektív } \\
\text { feldolgozása }\end{array}$ & $\begin{array}{l}\text { Salisbury-Glennon-- } \\
\text { Stevens, } 1999\end{array}$ \\
\hline $\begin{array}{l}\text { kezdő és tapasztalt tanárok } \\
\text { reflektív gondolkodása }\end{array}$ & kérdöív & Szivák, 1999a,b \\
\hline $\begin{array}{l}\text { felvételizők nevelői attitűdje, } \\
\text { pályaalkalmasság }\end{array}$ & $\begin{array}{l}\text { irodalmi szemelvényrészletek } \\
\text { feldolgozása }\end{array}$ & $\begin{array}{l}\text { Hunyadyné-Ungárné, } \\
1999\end{array}$ \\
\hline hallgatók és mentoraik nézetei & fogalomtérkép és mondatbefejezés & $\begin{array}{l}\text { Zantig-Verloop- } \\
\text { Vermunt, } 2001\end{array}$ \\
\hline jelöltek a tanításról, a jó tanárról & metaforaelemzés & $\begin{array}{l}\text { Vámos, 2001, } \\
\text { 2003a,b }\end{array}$ \\
\hline $\begin{array}{l}\text { tanárok nézetei és gyakorlati } \\
\text { tudása }\end{array}$ & strukturált interjú & $\begin{array}{l}\text { Golnhofer-Nahalka, } \\
2001\end{array}$ \\
\hline $\begin{array}{l}\text { mentorok gyakorlati tudása és } \\
\text { tanítási gyakorlata - hallgatók } \\
\text { saját gyakorlati tudásának } \\
\text { fejlődése }\end{array}$ & $\begin{array}{l}\text { támogatott felidézés és } \\
\text { fogalomtérkép }\end{array}$ & $\begin{array}{l}\text { Meijer-Zanting: } \\
\text { Verloop, } 2002\end{array}$ \\
\hline $\begin{array}{l}\text { nézetek a hatékony, sikeres } \\
\text { tanárról }\end{array}$ & kérdőív & $\begin{array}{l}\text { Minor- } \\
\text { Onwuegbuzie- } \\
\text { Witcher, } 2002\end{array}$ \\
\hline $\begin{array}{l}\text { hallgatók belépő nézeteinek } \\
\text { feltárása }\end{array}$ & $\begin{array}{l}\text { fogalomtérkép, résztvevő } \\
\text { megfigyelés, metaforaalkotás, } \\
\text { kvalitatív szövegelemzés }\end{array}$ & Dudás, 2007 \\
\hline $\begin{array}{l}\text { tanárrá válás (szakmai énkép, } \\
\text { szakmai identitás kialakulása) }\end{array}$ & $\begin{array}{l}\text { kérdőív, interjú, fogalomtérkép, } \\
\text { metafora }\end{array}$ & Köcséné Szabó, 2007 \\
\hline $\begin{array}{l}\text { pedagógusszerepek, pedagógus- } \\
\text { személyiség, pedagógusképzés }\end{array}$ & mesealkotás, meseelemzés & Vámos, 2008 \\
\hline pedagógusjelöltek nézetei & $\begin{array}{l}\text { szakirodalmi szövegek interaktív és } \\
\text { reflektív feldolgozása }\end{array}$ & $\begin{array}{l}\text { Bárdossy-Dudás, } \\
2011\end{array}$ \\
\hline
\end{tabular}


Wubbels (1992) azt feltételezte, hogy a hallgatói nézetek, prekoncepciók világképet alkotnak, szimbólumokkal írhatók le és úgynevezett jobbagyféltekestratégiákkal tárhatók fel és befolyásolhatók. Dudás $(2007,53$.) összegzése szerint „a tapasztalatok nyomán kialakult nézetek, elkötelezettségek, vélekedések a pedagógusok, hallgatók gondolkodásának mélyén húzódnak meg. Elemeik képekben, élményekben rögzülnek, a fogalmi gondolkodás számára nehezen hozzáférhető, nem mindig fejezhetők ki verbálisan.” Ezen argumentumok kutatási technikáim és eszközeim megválasztásakor rendkívüli fontossággal bírnak.

\section{A kutatás jellemzése}

\section{A kutatás célja}

Nemzetközi tanulmányok, kutatások igazolják a pedagógusok - és kompetenciáik, felkészültségük, körülményeik - meghatározó szerepét a tanítási-tanulási folyamat sikerében (pl. Teachers Matter, 2005; TALIS 2008). Kutatásom fókuszában a kétnyelvü fejlesztési feladatokat ellátó pedagógusok és pedagógusjelöltek kompetenciái, azon belül is kiemelten nézetei állnak, melyek nagymértékben befolyásolják a pedagógusképzés, illetve az intézményes kétnyelvü fejlesztés hatékonyságát (lásd a teljes kutatást a szerző doktori értekezésében). A jelen tanulmány keretei között bemutatott kutatás céljai a következők:

- Az ELTE Tanító- és Óvóképző Kar kétnyelvi képzésében részt vevő hallgatók nézeteinek megismerése a korai kétnyelvü fejlesztésre, a kétnyelvi pedagógusi feladatokra és a képzés/önképzés szerepére vonatkozóan.

- A pedagógusképzésben hatékonyan alkalmazott, vizuális megjelenítést igénylő kreatív tevékenységek és technikák kvalitatív kutatásmódszertani kipróbálása és alkalmazhatóságuk, megbízhatóságuk igazolása.

\section{A kutatás kérdései}

Kutatási céljaimhoz kapcsolódóan a következő két kérdésre keresem a választ több projektív technika segítségével, közöttük a jelen tanulmányban bemutatott vizuális megjelenítést igénylö alkotások elemzésével.

- Milyenek a kétnyelvi pedagógusjelöltek nézetei saját majdani szerepükről, hivatásukról, feladataikról és a szükséges kompetenciákról? Milyenek a nézeteik a kétnyelvüségről, a kétnyelvi pedagógussá válás folyamatáról?

- Alkalmasak-e a pedagógusképzésben általam alkalmazott tevékenységek, módszerek és technikák pedagóguskutatási és pedagógusképzés-kutatási célok megvalósítására; hallgatói nézetek feltárására, tanulási eredmények (Learning Outcomes, LeO) megismerésére?

\section{A kutatás módszerei és technikái}

A teljes kutatásban metafora- és meseelemzést, kérdőíves vizsgálatot, hallgatói reflexiók és hivatalos dokumentumok elemzését, mondatbefejezést, szimulációs, valamint egyéb projektív technikákat alkalmaztam. A jelen tanulmányban 
bemutatásra kerülő vizsgálat során vizuális megjelenítésen alapuló alkotások elkészítésére kértem a hallgatókat egyénileg, párban, illetve kooperatív kiscsoportokban. A hallgatói munkák között rajzok-festmények, különféle (pl. origami, kollázs) technikájú poszterek, társasjátékok, folyamatábrák és rajzos fogalmi térképek szerepeltek. Legtöbbször szóbeli kikérdezés és több esetben írásbeli reflexió is segítette a hallgatói alkotások értelmezését (ez utóbbira példák a Függelékben találhatók). Kutatásetikai megfontolásból a bemutatott alkotások, írásbeli elemzések csak abban az esetben szerepelnek névvel együtt, ha ehhez az illető hallgató hozzájárult.

\section{A kutatás folyamata és mintája}

Elővizsgálatként a Kétnyelvü Iskoláért Egyesület (KIE) 2003-ban akkreditált kétnyelvi pedagógustovábbképző kurzusán oktatóként betekintést nyerhettem 40 pedagógus kolléga témához kapcsolódó nézeteibe (2007-ben n=15, 2008-ban $\mathrm{n}=25$ ). Az általam 2007-ben és 2008-ban tartott két mühelyfoglalkozás során számos interaktív, kreatív, a személyes elméleteket, prekoncepciókat felszínre hívó tevékenységi formát kipróbáltam. Az alkalmazott projektív technikák, többek között a mondatbefejezés, a receptalkotás, a szimulációs szerepjátékok és a vizuális tevékenységek kifejezetten alkalmasaknak bizonyultak a pedagógusnézetek feltárására, képzési és kutatási szempontból egyaránt. Rajtuk keresztül megismerhetőkké váltak a kétnyelvüséggel kapcsolatos pedagógusnézetek, a kétnyelvi pedagógus számára szükséges kompetenciák, valamint a pedagógusképzés és -önképzés feladatai és lehetőségei.

Ezen tapasztalatok alapján a 2011-2012 és a 2012-2013 tanév három félévében az ELTE Tanító- és Óvóképző Karán a meghirdetett kétnyelvi óvodapedagógusképző specializáció kurzusain, valamint a tanító szakos hallgatók számára szabadon választható kétnyelvüségi modul keretében kértem a jelölteket vizuális megjelenítésü alkotások készítésére nézeteik megismerése céljából (összesen: $n=90$, ebből 90\% óvodapedagógus, 10\% angol műveltségterületi tanító, a nappali tagozatos jelöltek aránya $85 \%$, az esti tagozatos hallgatóké $15 \%$ ). A tanulmányban bemutatásra kerülő alkotások kétnyelvi módszertani szemináriumokon, kooperatív munkaformákban vagy a „Kétnyelvűség elmélete és gyakorlata" elnevezésü kurzushoz kapcsolódó portfóliók számára egyéni, otthoni feladatként születtek. Egyes jelöltek több alkotást is készítettek (például rajzot és társasjátékot is). A továbbiakban 80 , vizuális szempontból értelmezhetőértékelhető kreatív alkotást elemzek a teljesség igénye nélkül, kizárólag a kétnyelvi pedagógusi kompetenciák megismerése céljából. A példák segítségével bemutatom a hallgatók kétnyelvü fejlesztéssel, a kétnyelvi pedagógus szerepével kapcsolatos nézeteit, illetve kitérek a kétnyelvi pedagógussá válás folyamatára és a pedagógusképzés feladatára is. 


\section{A kutatás eredményei}

\section{A kétnyelvi pedagógusra vonatkozó hallgatói nézetek}

A hallgatók kétnyelvi pedagógust ábrázoló rajzai, alkotásai nagyon változatosak. Vannak köztük olyanok, amelyek otthoni elkészítése láthatóan több munkaórát is igénybe vett, és nagyfokú kreativitásról, valamint esetenként müvészi hajlamról is tanúskodik. Mindenféleképpen pozitívan értékelendő, hogy a hallgatók többsége sem időt, sem energiát nem sajnált a müvek elkészítésekor, s ez a tény egyben a feladat megfelelő motivációs értékét is tükrözi. Természetes, hogy a hallgatók tehetségben, látásmódban, nézeteikben különböznek, és nincs ez másképp a vizualitás, a müvészeti ágak és stílusirányzatok terén sem. Ebből következően a hallgatói alkotások is mind teljesen egyediek, alig összehasonlíthatóak. Ugyanakkor a rajzokból, a kollázsokból és az egyéb technikákkal készített kétnyelvi pedagógusi ábrázolásokból (megerősítve azokat alkotóik szóbeli és írásbeli beszámolóival), a személyes filozófiákra nézve több tanulság is levonható, a teljesség igénye nélkül.

A vizuális megjelenítéseket a metaforákból és a mesékből kirajzolódó, komplex tevékenységet folytató, sokszínü személyiséggel, változatos pedagógiai készségekkel és kompetenciákkal rendelkezö kétnyelvi pedagógussal összevetve (lásd a szerző doktori értekezése, valamint Trentinné, 2008, 2013) megállapítható, hogy a verbális és a nonverbális kreatív alkotások számos egyezöséget, párhuzamot mutatnak. Megjelennek a rajzokban is az egyes metaforikus elemek, többek között a rugalmasságot jelképező rugó, az alapokat jelző téglák, a tudást szimbolizáló könyvek, a nyelvi kompetencia jeleként a szótár, az egyes fejlesztési területek piktogram-szerü jelölései, valamint a játékosság megfelelőjeként a labda és a mackó. 


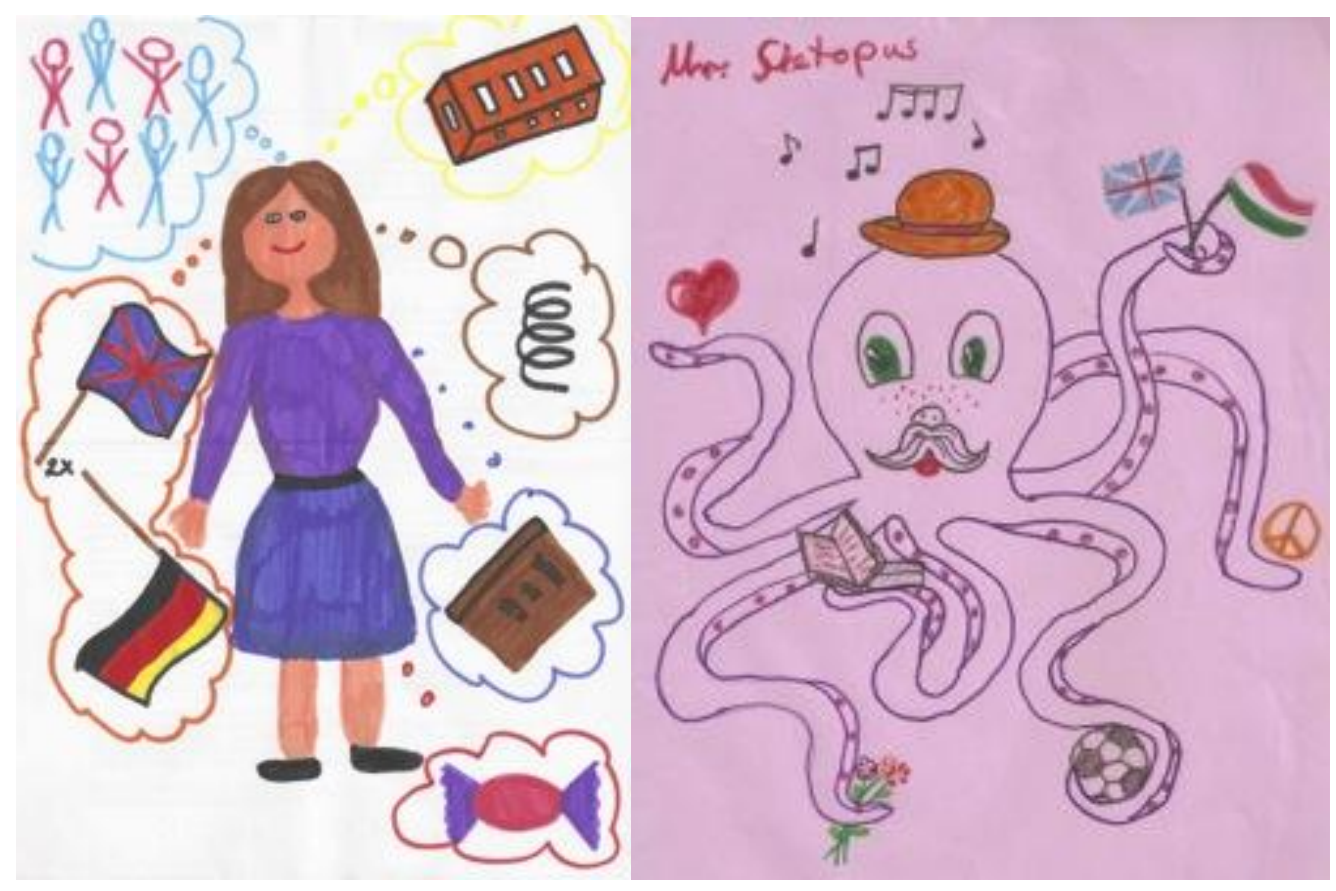

1. ábra: Hallgatói rajzok a jó kétnyelvi pedagógusról

A további - metaforákban és rajzokban egyaránt megjelenő - jellegzetes elemek közé tartozik a sokszínüséget megtestesítő szivárvány, a varázspálca, a multifunkcionális tevékenységre lehetőséget teremtő sok testrész, több pár kéz, láb, szem, sőt nyelvből is kettő jut a két nyelven egyformán kommunikálni képes pedagógus-csodalénynek. A rajzokból - hasonlóan a mesékhez és metaforákhoz egyértelmüen kiderül, hogy a kétnyelvi pedagógusnak számos kompetenciával kell rendelkeznie: többek között tudnia kell énekelni, mesét mondani, játszani, mókázni, zenélni, altatni, építeni, táncolni, futkosni, homokozni, enni adni, varázsolni, vágni-ragasztani, színezni, számolni, festeni, sportolni és legfőképpen szeretni. 


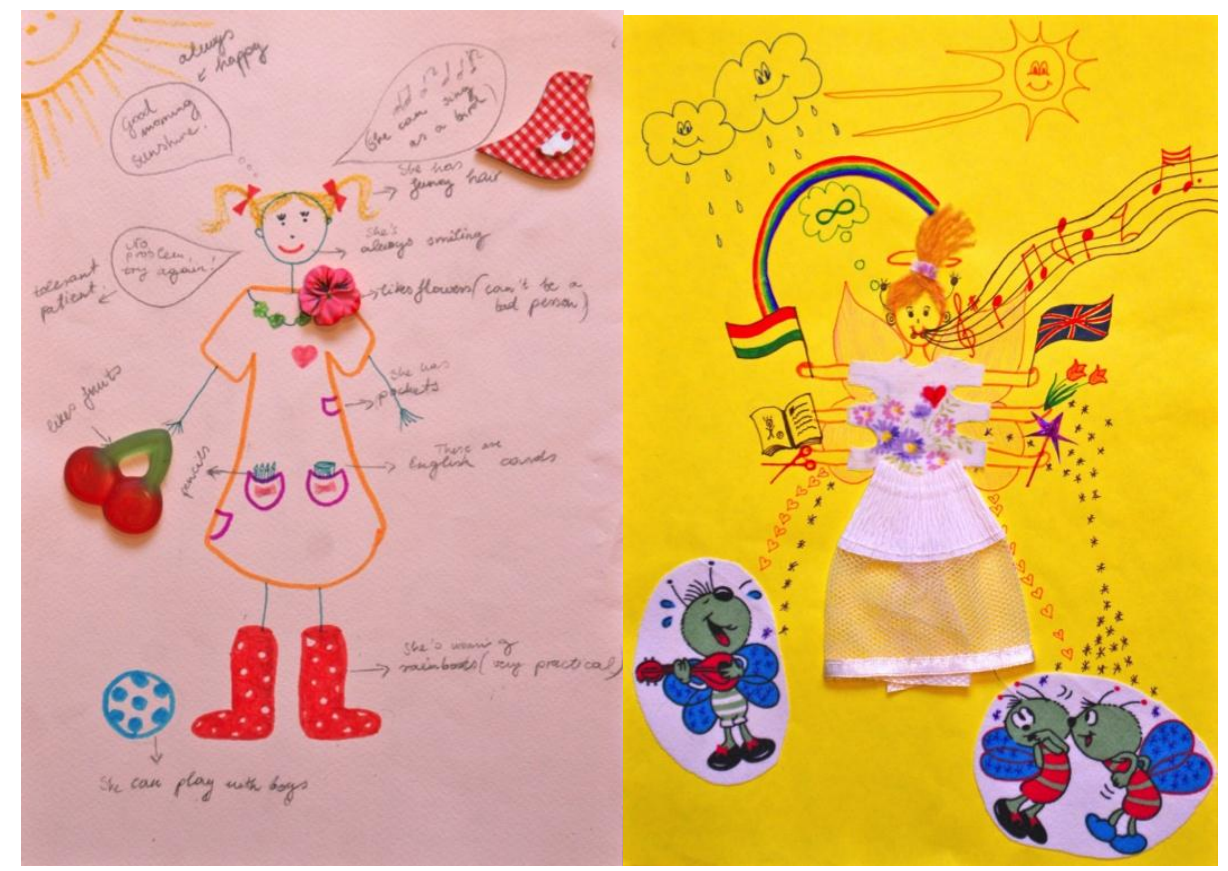

2. ábra: Hallgatói (térbeli) alkotások a jó kétnyelvi óvodapedagógus ábrázolására

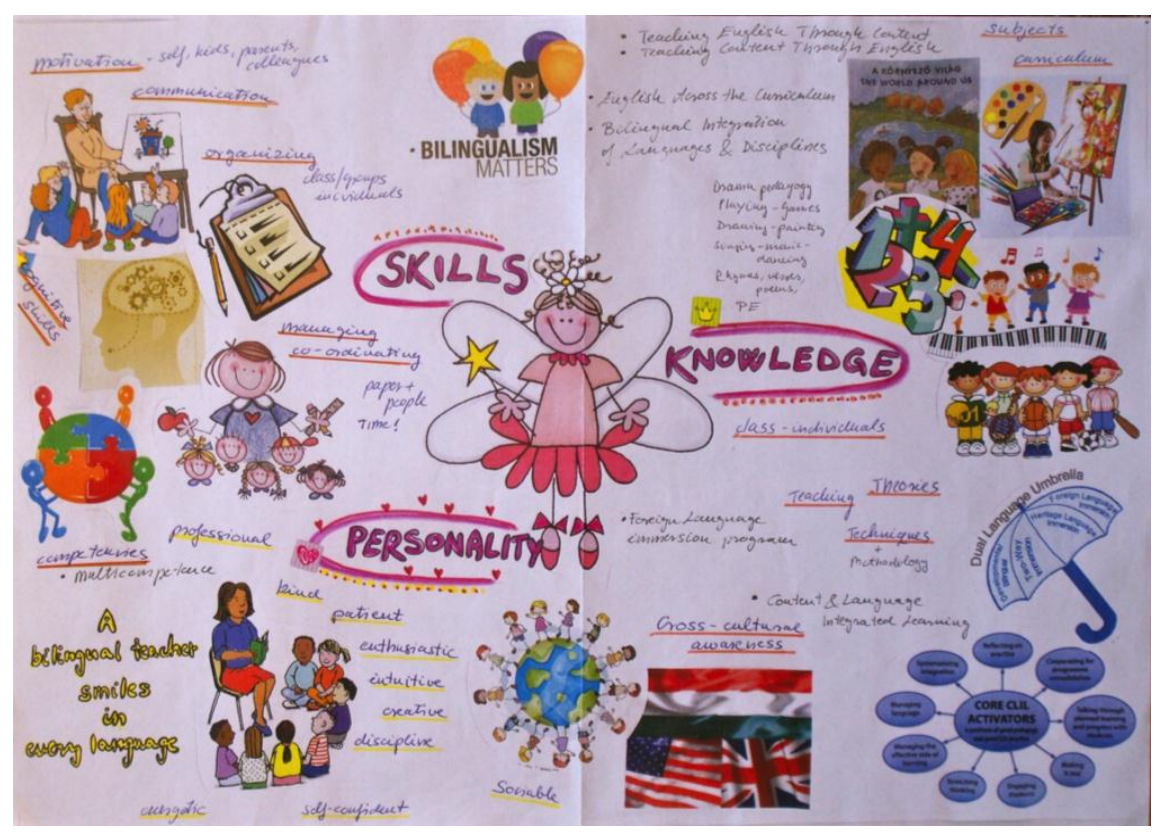

3. ábra: Az ideális kétnyelvi pedagógus (Maródi Zsófia munkája: poszter, mérete: A3) 


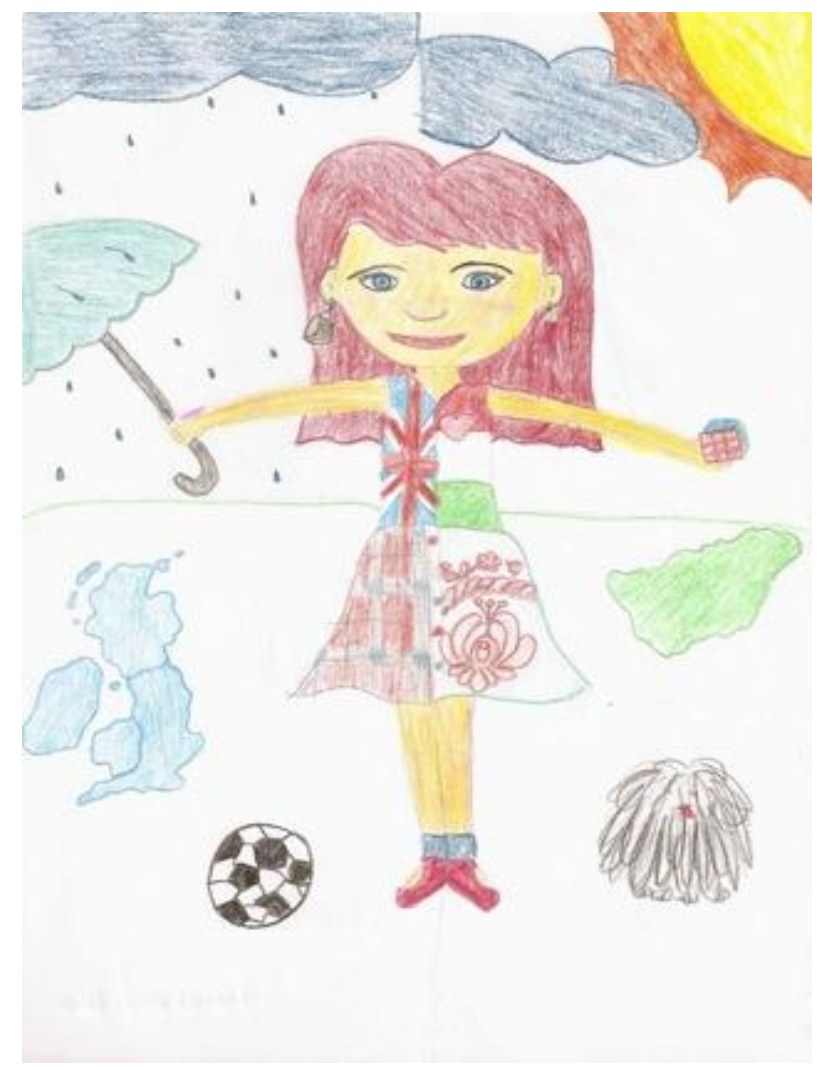

4. Ábra: Az interkulturális ismeretek megjelenése (Marschalkó Dóra rajza)

A legtöbb alkotáson található utalás konkrétan a kétnyelvüségre is, általában a magyar és az angol vagy az amerikai zászló segítségével, ugyanakkor van olyan hallgató is, aki a többnyelvüség fontosságának hangsúlyozása érdekében az angol és a német zászlót együtt jeleníti meg. Az országokra, nemzetekre történő utalások egyéb lehetőségei a „kisbetűs” kultúra értelmezésében (vö. Kramsch, 1994; Laidlaw, 2001; Kovács, 2009), a célnyelvi ország szimbólumaiban, mint például a piros emeletes londoni busz képében teljesednek ki. Az interkulturális szempontból egyik meghatározó alkotáson (4. ábra) jól felismerhető az angol foci és a magyar pulikutya, az eső és a napsütés, a skót szoknya és a magyaros népviselet, az esernyő és a Rubik-kocka, valamint az ötórai teázást jelképező teás csésze és a makói pirospaprika fülbevalók, még a feltüntetett országzászlók és térképek nélkül is. A hallgató saját alkotásának szóbeli interpretálása során kiemelte, hogy a képen megnyilvánuló kettősség egységének ábrázolása mellett a kétnyelvi pedagógus szíve - a rajzon külön is jelölve - a magyar, azaz a haza oldalán van. Ez is sugallja, hogy a kétnyelvüség nem okoz identitásbeli problémát, és nem jelent veszélyt a nemzeti hovatartozásra, hazafias érzelmekre.

A jellemző pedagógusi személyiségjegyek kapcsán érdemes kitérni arra is, hogy a hallgatók szinte mindig mosolygós, vidám pedagógust jelenítenek meg alkotásaikban. A belsö pozitív tulajdonságokra utalva a legtöbb rajzon feliratok, beszéd- és gondolatbuborékok olvashatók angol és/vagy magyar nyelven, melyek többek között a toleranciára, a türelemre, a gyermekszeretetre, a kedvességre, az empátiára hívják fel a figyelmet. Ezeket az elengedhetetlen személyiségjegyeket, 
attitűdöket erősíti az alkotásokon szereplő számos kiegészítő elem is, mint például a béke szimbólumának megjelenítése vagy a „szív” és a „virág” ábrázolása, utóbbi azzal a megjegyzéssel, hogy „ha szereti a virágot, rossz ember nem lehet”.

A hallgatók többsége - szövegszerủen is hangsúlyozva - fiatal, csinos, ,jó illatú”, „könnyed mozgású”, szép nőként, míg mások kedves, középkorú, kissé teltkarcsú, teljesen átlagos külsejü asszonyként ábrázolják az ideális kétnyelvi óvodapedagógust. Akad néhány példa az állat képében (pl. polip, pók) való megjelenítésre is, kihangsúlyozandó egyes speciális képességeket, valamint fellelhető egy-két alkotáson férfi pedagógus szerepeltetése a pedagóguspálya elnőiesedésére történő utalással. Ahol fiatal nőként jelenítik meg, ott számos egyéb külsö jellegzetesség is megfigyelhető: többek között a hosszú - sok esetben „vicces” - frizura, szép sürü, nagy szempilla, divatos kiegészítők, illetve színes, mintás, egyedi, időnként kimondottan bohókás, feltűnő vagy trendi, esetleg ritkábban elegáns öltözet. A ruha anyagában, mintájában, színében többször megjelennek a magyar zászló és a célnyelvi ország zászlójának színei és motívumai. Ugyanakkor találhatóak példák teljesen egyszínü és mindennapi viseletre, pulóver és szoknya megoldásra is.

Egyes hallgatók a szóbeli beszélgetés során is fontosnak tartották kiemelni, hogy a szoknya elengedhetetlen ruhadarab, és volt olyan is, aki egyéb nőiességet sugalló-erősítő kiegészítést is megfogalmazott, mint például a magas sarkú cipőt. Ennél ugyanakkor sokkal jellemzőbb megoldás az öltözék tekintetében a hasznosság figyelembevétele, mint például a sportcipő, amely kényelmes viselet a játékhoz és minden egyéb, aktív testmozgást igénylö foglalkozáshoz. Jellemző lábbeli továbbá az ,angolos” gumicsizma, a praktikusságára vonatkozó hozzáfüzött megjegyzéssel. Ugyanilyen meggondolásból több alkotás közös jellemzője a pedagógus ruházatán található sok, nagyméretü zseb, melyekben színes ceruzáktól a játékkártyákon át a mesekönyvekig minden elfér. Nincs különbség a vizsgálatban szereplő kétnyelvi tanító és a nagyobb létszámú óvószakos hallgatók ábrázolásai között. Jellemzően ugyanazok az elemek, kiegészítők és szimbólumok jelennek meg az alkotásokon (lásd 5. ábra). 

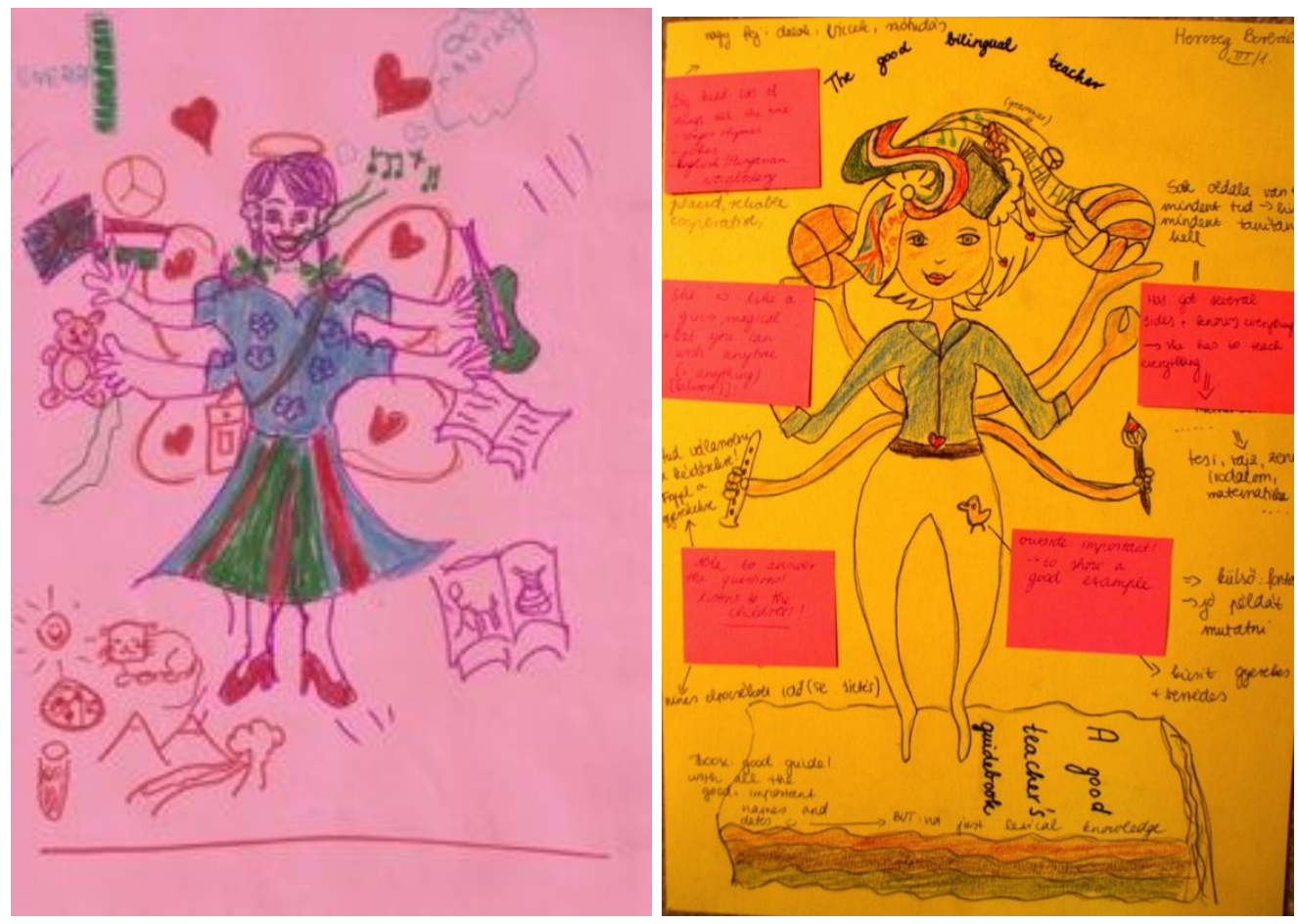

5. ábra: Hallgatói alkotások - kétnyelvi pedagógusi kompetenciák, személyiségjegyek (óvopedagógus és tanító szakos jelöltek 1-1 rajza)

A 6. ábrán, egyedi megoldásként, a hallgató fénykép formájában saját maga jelenítette meg a jó kétnyelvi pedagógust a szükséges kompetenciákra és alapelvekre történő utalásokkal kiegészítve (lásd a 3. mellékletet).

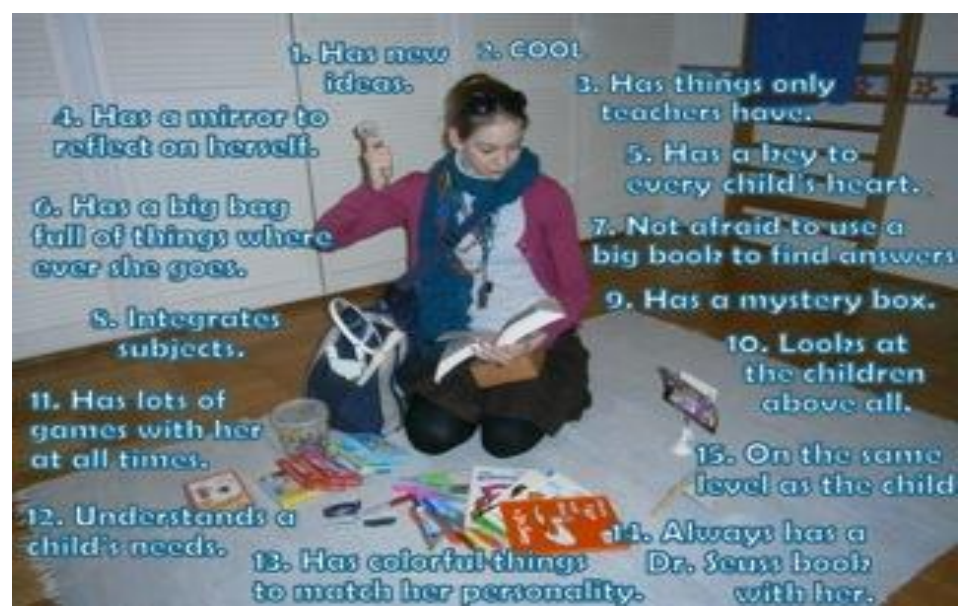

6. ábra: A jó kétnyelvi tanító jellemzői (Taylor Jennifer)

Minden alkotásra jellemző annak a nézetnek a megjelenése, hogy a kétnyelvi pedagógus kedves, szerethető egyéniség, aki rendelkezik számos nélkülözhetetlen szakmai és személyes kompetenciával. A legtöbb rajzon és szöveges reflexióban fontos elemként jelenik meg a külsö és belsö szépség egysége, amint az az egyik poszteren angolul olvasható is: ,,a kétnyelvi pedagógus minden nyelven mosolyog". Ugyanakkor meglepő, hogy a jellemzően azonos 
életkor ellenére a külső jegyek megjelenítésekor mennyire eltérő példákmintázatok, emlékképek és ideálok hatásai érvényesülnek. A hallgatói munkák stílusukban az ideális kétnyelvi pedagógus vizuális leképezésekor a teljesen hagyományos, a hatvanas éveket idéző emberábrázolásoktól az ultramodern megjelenítésekig széles skálán mozognak, csakúgy mint az alkalmazott technikák tekintetében.

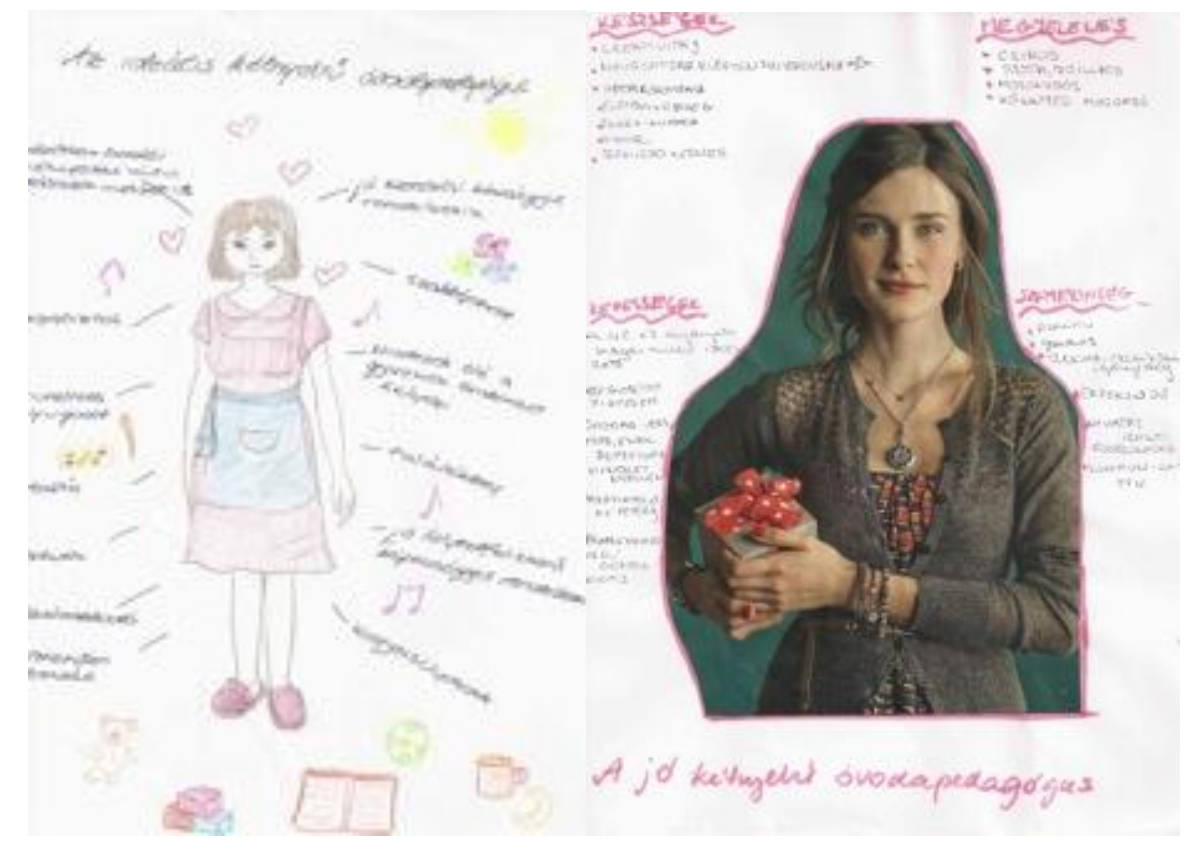

7. ábra: Hallgatói alkotások - emlékképek és ideálok?

Az eltérő, változatos felfogású alkotások tekintetében terjedelmi és tartalmi korlátok miatt nem mutatok be minden típusra példát, de a stílusok - és ezáltal a pedagógusnézetek - tekintetében mindenképpen fontos néhány kiemelkedő alkotásra felhívnom a figyelmet. Olyan példákat választok, amelyeken a külső és belső szépség egyensúlya, a mondanivaló és a megjelenítés módja együttesen fejezi ki a korai kétnyelvü fejlesztés lényegét és ebben a pedagógus szerepét. Az egyik ilyen hallgatói munka egy nagyméretü, térbeli, origami technikával készített alkotás (8. ábra). 


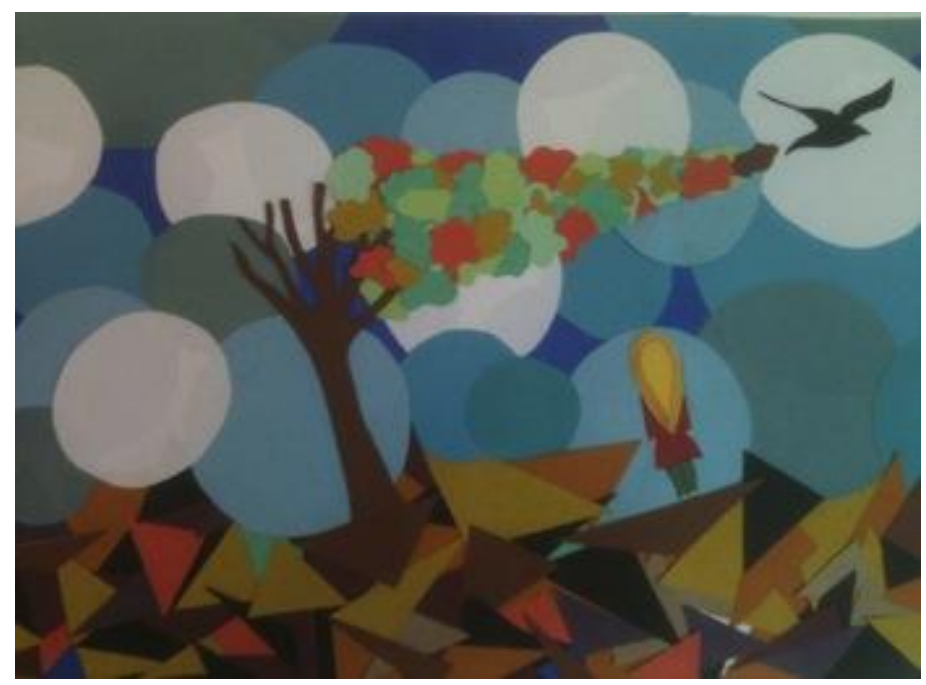

8. ábra: Nagyméretü, térbeli - origami technikával készített - alkotás (Fuller Fanni)

- „A képen a lány egy kétnyelvű óvodapedagógust ábrázol (engem): az alsó háromszögek a nehézségeket ábrázolják, amelyekkel egy kétnyelvü óvodapedagógusnak meg kell küzdenie (nyelvi nehézségek, a külvilág negatív véleménye stb...). Az óvónő ezeken túljutva, a nehézségek fölött áll. A madár a gyerekeket ábrázolja, akik az óvónő munkájának »gyümölcsét « viszik magukkal. A kék háttér a lekerekített formákkal a megbízható hátteret szimbolizálja, amelyet az óvónő teremt meg, ebben a közegben a gyerek nyugodtan kibontakozhat (kibonthatja szárnyait)."

Egy teljes nézetrendszer feltárására is alkalmas lehet egy vizuális feladat az egyén alkotói képességeinek bemutatásán túl. A következő képről (9. ábra) is sugárzik a harmónia. Megtalálható benne a holisztika gondolata, a természetes nyelvelsajátítás folyamatára, körülményeire történő utalás, a társas interakció során megvalósuló nyelvi fejlődés, a pedagógus személyiségének, külső-belső szépségének összhangja, s megjelenik a többnyelvüség és a multikulturalitás eszméje, valamint a pedagógus által megvalósított varázslás-energia-szeretettudás közvetítése és a motiváció csodája. A hallgató elemzése a Függelékben olvasható (lásd 1. melléklet). A két/többnyelvüségre, a kétnyelvű fejlesztésre, a pedagógus szerepére vonatkozóan ismerhető meg a hallgató személyes filozófiája:

- „A ruha jobb oldalán Nagy-Britannia zászlajának mintája, a balon pedig Magyarországé látszik. A két zászló színei közül a pirosak összeolvadnak, színátmenetet képez a szoknya redőzete. Ez egyértelműen arra mutat, hogy milyen játékosan és határok nélkül lehet tanulni/tanítani idegen- és anyanyelvet óvodás korban."

- „ „A képen a kisgyerekek szemben az óvodapedagógussal ülnek vagy fekszenek. Igyekeztem érzékeltetni a különböző etnikumú gyerekek összetételét, ezzel utalva a kétnyelvüségre. Mindannyian figyelnek a mesére, amit az óvónő fejből mond el. Nagyon fontos ez ahhoz, hogy hiteles legyen a mese, mert így van (szem)kontaktus a mesélő és a hallgatóság között." 


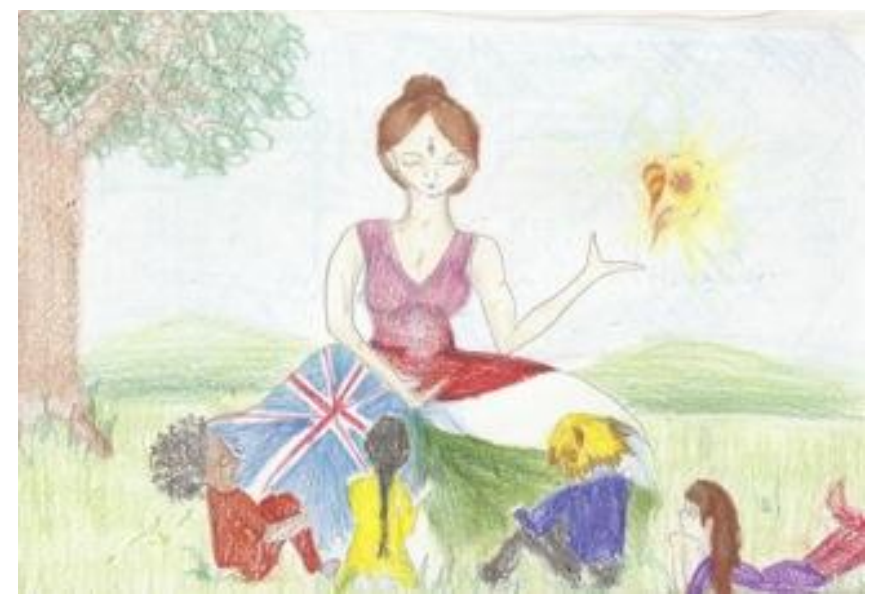

9. ábra: Szabó Tímea rajza a kétnyelvi pedagógusról és a természetes nyelvelsajátításról

Egy teljesen eltérő világot és pedagógust tükröz a következő kreatív hallgatói munka (10. ábra). Látásmódja egyéni, egyedi. Rajztechnikai stílusa bevallottan is - a kortárs japán manga-képregény világához áll a legközelebb. A forma, a színek, a technika minden szempontból más, mint az eddig bemutatott alkotások esetében, ugyanakkor a téma ugyanaz: a korai kétnyelvi pedagógus sokrétü személyiségének és szakmai kompetenciáinak hatásos megjelenítése. A fekete-fehér vonalrajzzal ábrázolt „pókhölgy” első pillantásra szokatlan, meglepő választásnak tünik, ugyanakkor a hallgató szóbeli és írásbeli indoklása alapján érthetővé és relevánssá válik. A valóságos pók sok szemével mindent lát, lábaival minden irányba és minden felületen képes gyorsan elmozdulni, ezért számos szempontból ideális pedagógusfigura. A ,gyermekeket észrevétlenül összetartó” hálójában (birtokában) lévő tárgyak képében megjelenő pedagóguskompetenciák a kétnyelvi pedagógus sokrétü - külső és belső térben végzendö - tevékenységeire utalnak. (A hallgató saját rajzáról írt teljes szövegủ reflexióját lásd: 2. melléklet.) 


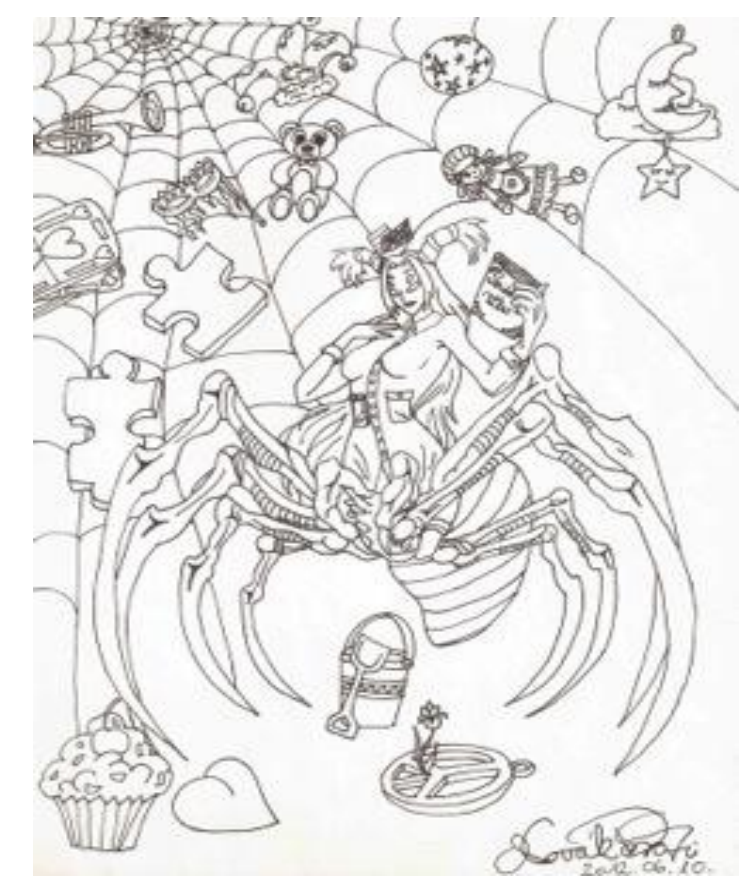

10. Ábra: Novák Doroti rajza a kétnyelvi pedagógusról

- Miért is kéne egy emberalakot öltött pedagógust lerajzolnom? Nem kell! ... Számomra egy tökéletes óvodapedagógusnak nagyon fürgének kell lennie, de ugyanakkor észrevétlennek is. Mindent át kell látnia, de úgy, hogy ezzel ne zavarja meg a gyerekek tevékenységeit. Össze kell tartani a gyerekeket, de az ne legyen egy kötelező feladat számukra, hanem inkább egy kellemes játék."

- „ „Ha szemügyre vesszük a rajzom, igazán nem titok, hogy kissé félelmetesre sikerült a pedagógusom. DE! Ezzel is azt szerettem volna ábrázolni, hogy nem igazán a külső a lényeg, hiszen bárhogyan nézhet ki egy pedagógus, ha meleg szíve van, és ha jól végzi a feladatát... A pók is egyfajta óvodapedagógus, nem? Rengeteg kicsinye kel ki, akiket a hátán hordoz, nevel és véd. Az állatvilágban is megtalálhatjuk a óvodapedagógusokat!"

Összességében tehát megállapítható, hogy a hallgatói alkotásokon keresztül szerethető, tiszteletet ébresztő, komoly hivatásként kiteljesedő misszióvá válik a korai kétnyelvi pedagógusi tevékenység. Hol egyszerü, hétköznapi feladatként, hol varázslatos, emberfeletti misztikumként ábrázolódik a kétnyelvü fejlesztés. Minden esetben mégis természetes, harmonikus folyamatként, egyszerre nyugalmas, de mégis izgalmas, motiváló kihívásként ismerhető meg a kétnyelvi pedagóguspálya a hallgatók kreatív munkáiból.

\section{A kétnyelvi pedagógussá válás folyamata}

Az alábbiakban a teljesség igénye nélkül bemutatom a begyüjtött alkotások alapján körvonalazódó hallgatói nézeteket a kétnyelvi pedagógussá válás tekintetében. A fogalmi térképekből, társasjátékokból és egyéb kreatív munkákból kiderül, hogy a jelöltek ismerik és értik a kétnyelvü fejlesztéssel kapcsolatos főbb feladatokat és kihívásokat, a kapcsolódó területeket, valamint a sikeres munkavégzéshez szükséges pedagóguskompetenciákat. 

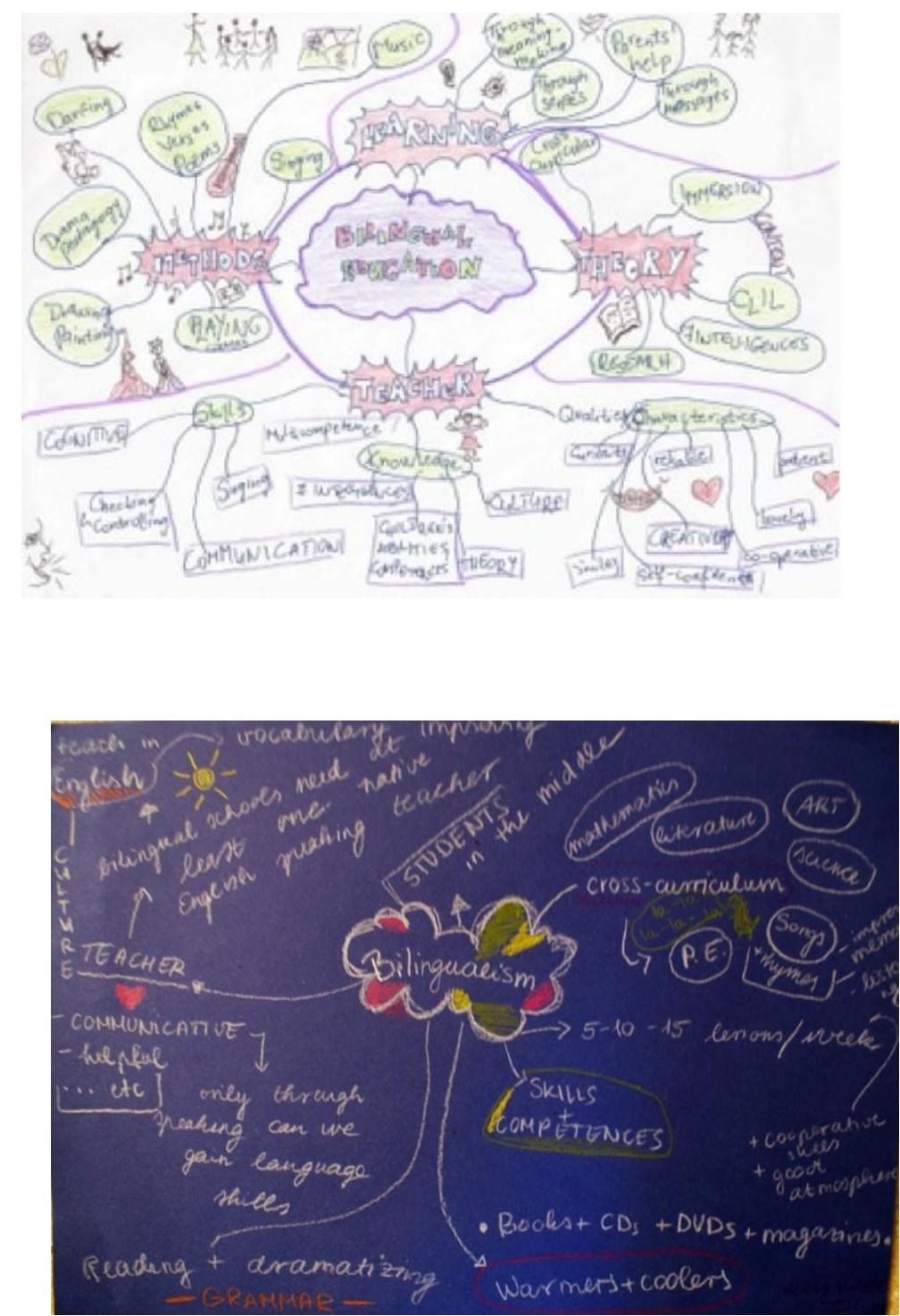

11. ábra: Hallgatói fogalomtérképek a kétnyelvü fejlesztésről

A társasjátékok számos érdekes tanulsággal szolgálnak pedagógusképzéskutatási szempontból. Megállapítható, hogy a jelöltek tudatában vannak a kurzusok során elvárt tanulási eredményeknek, valamint a kétnyelvi pedagóguskompetenciák megszerzését segítő képzési-önfejlődési lehetőségeknek. Ismerik a pályaszocializáció, illetve a majdani pályavitel folyamatát. A jelöltek többsége képes a módszertani szakkifejezések célnyelven való alkalmazására és saját elképzeléseinek kreatív, vizuális megjelenítésére egyaránt. A kétnyelvi pedagógushallgatók képesek egyrészt önálló tervező és alkotó tevékenységet végezni, másrészt egy konkrét feladat megoldása érdekében, adott időkeretben, egymással együttmüködve, elképzeléseiket ütköztetve és összehangolva közösen dolgozni. Mindezek igazolására bemutatok néhány - egyénileg otthon vagy kooperatív munkaformában szemináriumi keretek között elkészített társasjátékot, illetve társasjátékvázlatot. 
Az egyik csoportmunkában elkészített társasjátékterv fő mezőiben nemcsak a kétnyelvü fejlesztéshez szükséges pedagóguskompetenciák birtoklásamegszerzése kap helyet (pl. kreativitás, kommunikációs készségek, kultúra- és nyelvismeret, nyelvi alapkészségek, nyelvtan, szókincs, CLIL-ismeretek, magabiztosság, nyitottság, gyermekszeretet, vidámság, megfelelő attitűdök stb.), hanem a különböző kiemelt fejlödési lehetöségek is megjelennek. Utóbbiak közül például ilyen az egyetemre (ELTE TÓK) való bejutás vagy az Erasmus részképzés, illetve a célnyelvi gyermekirodalom megismerése. Ezen mezőkre lépve a játékos könnyebben és gyorsabban juthat elöre nemcsak a társasjátékban, hanem a való életben is. A társasjáték kezdeti lépései, az alapvető adottságok, mint a lelkesedés és a gyermekszeretet után következő képzési-önfejlesztési folyamat utolsó öt mezője a végcél előtt: 1. tevékenységek tervezése gyerekeknek, 2. tapasztalatok szerzése, 3. tevékenységek tartása gyermekeknek, 4. a végzettség megszerzése, 5. munkahely, állás megszerzése. A célban a mosolygós, vidám pedagógus alakja látható a szintén elégedett, boldog gyermekek társaságában (12. ábra).

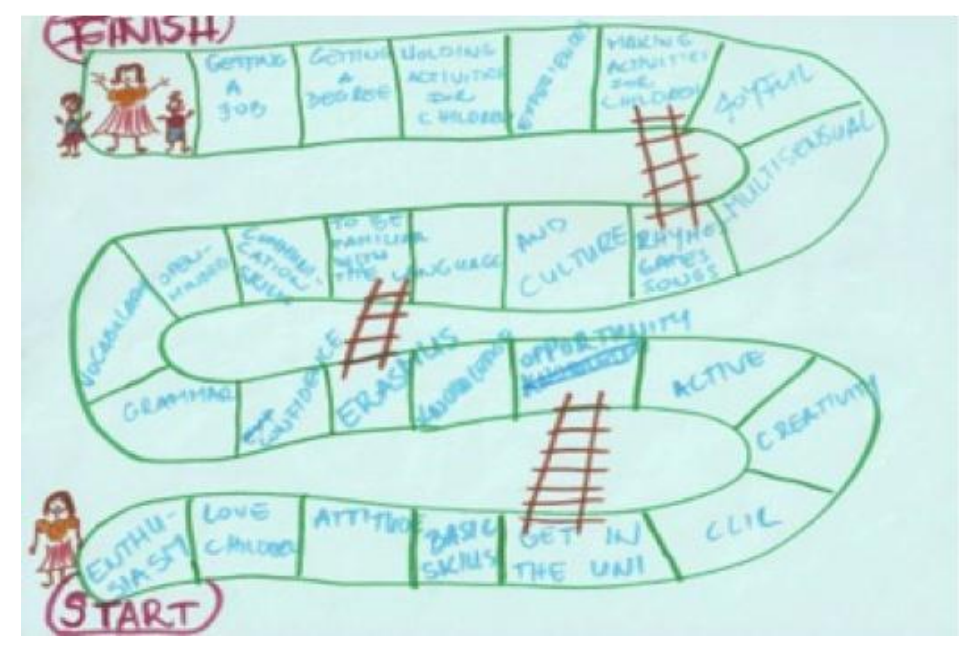

12. ábra: Hallgatói társasjátékterv a jó kétnyelvi pedagógussá válás folyamatáról (1)

Egy másik példában a start utáni legelső mezőben a következő olvasható (angolul): „Ha nem beszélsz jól angolul, kiestél.” Később is kieshet a játékos, ha a csoportjában lévő gyerekek nem érzik jól magukat az általa vezetett foglalkozásokon és nem élvezik az nyelvelsajátítási folyamatot. A további teljesítendő feladatok között szerepel az egy év szakmai gyakorlat, a három hónapos külföldi nyelvgyakorlás, a célnyelvi gyermek- és ifjúsági irodalom megismerése, az általános pedagógiai készségek megszerzése, sok dal, mondóka, mese, játék megtanulása, valamint a kétnyelvüség szakirodalmában való elmélyülés. Ezeket a lépéseket újabb gyakorlatok követik még a cél elérése előtt.

Ehhez hasonlóan, az összes társasjátékban szerepelnek a gyakorlat és az elmélet különböző formái. Előbbiekre számos példa található az egyik alkotásban, ahol a hospitálást, az intézményi megfigyelést szakmai gyakorlat követi, melynek 
keretében sor kerül a szülőkkel való beszélgetésre, az elsajátított anyag megfogalmazására csakúgy, mint a saját foglalkozások képi és hangi rögzítésére a reflexió, az önértékelés és az önfejlesztés érdekében. Szintén a gyakorlati fejlesztő program részét alkotja a saját kompetenciák fejlesztése (pl. zenei téren), az új ötletek felkutatása, valamint a közös családi-óvodai programok szervezése, valamint a szülők inspirálása a nyelvtanulásra. Ezen felül szerepel még anyanyelvi beszélőkkel való kapcsolattartás, valamint számos egyéb ismeret, készség és attitüd bizonyítása. Ezek közül is kiemelt szerepet kap a magyarul tanultak felhasználása, a nyitottság, a multikulturalitás (az ünnepekre, az irodalomra, a szokásokra, a zenére vonatkozóan), valamint a kétnyelvüséggel, a korai nyelvi fejlesztéssel kapcsolatos modern kutatási eredmények ismerete.

Minden társasjátékban hangsúlyos a gyakorlati pedagógiai-módszertaninyelvi készségek bizonyítása. Például pontlevonás, illetve visszalépés jár, ha a játékos nem elég kreatív, ha túl sokat beszél magyarul vagy ha kiabál a gyerekekkel; ugyanakkor pluszpontok járnak többek között az angol nyelvhasználatért, az együtt éneklésért, a gyerekek célnyelvi megnyilatkozásait kísérő türelemért (lásd például 13. ábra).

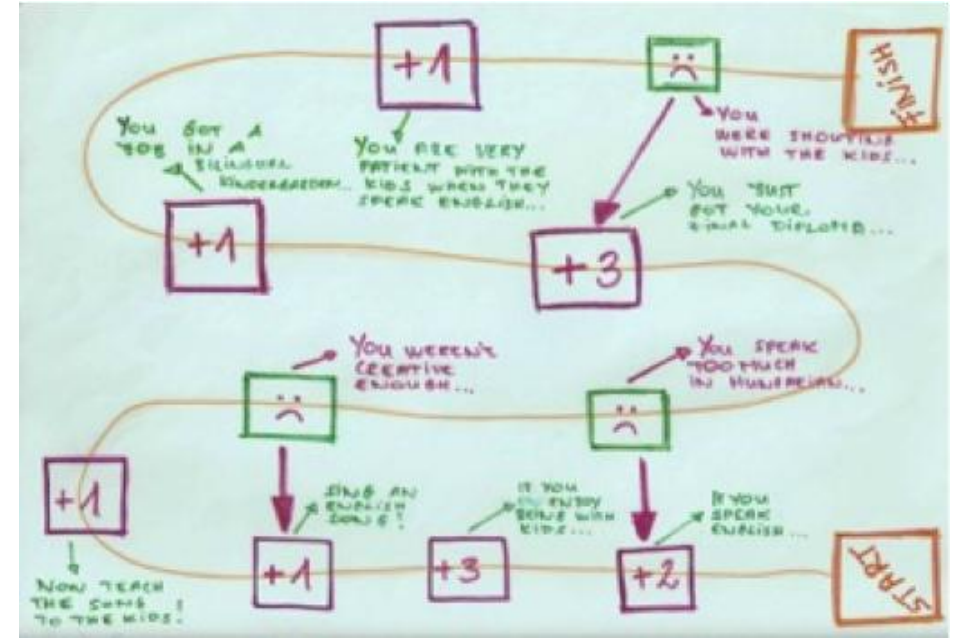

13. ábra: Hallgatói társasjátékterv a jó kétnyelvi pedagógussá válás folyamatáról (2)

Más társasjátékokban kiemelt szerephez jut a motiváció, a környezet, a szülők, valamint a gyermekek megismerése és „,boldoggá tétele”, a kitartás és az elszántság, továbbá megjelenik a portfólió is mint a szakmai fejlődés kihagyhatatlan eleme. Az említett példában az óvodai állás megszerzése nem a végcél, hanem egy köztes állapot, amelyet elöször (számos egyéb lépés közbeiktatásával) egy jelentős fizetésemelés, majd egy angol óvodában betöltendő pozíció és legvégül a saját óvoda megnyitása követ. Egy másik érdekes társasjáték-megoldásban a végcél előtt van egy ún. „question point” (államvizsga), ahol sikeres válasz esetén a célvonalhoz jut a játékos, de ha nem tudja a választ, akkor egy korábbi állomáshoz irányítják vissza. 
A kutatásban kisebb létszámmal részt vevő, kétnyelvi modult választó tanító szakos jelöltek társasjátékai is nagyfokú kreativitásról és tudatosságról tanúskodnak. Készült hallgatói alkotás Spongya Bob stílusban csakúgy, mint hagyományos „ki nevet a végén”, "”tabu” és ,activity” jellegü megközelítésben, valamint az angolszász gyermekkultúrából jól ismert „kígyók és létrák” (snakes and ladders) társasjáték mintájára (lásd 14. ábra).
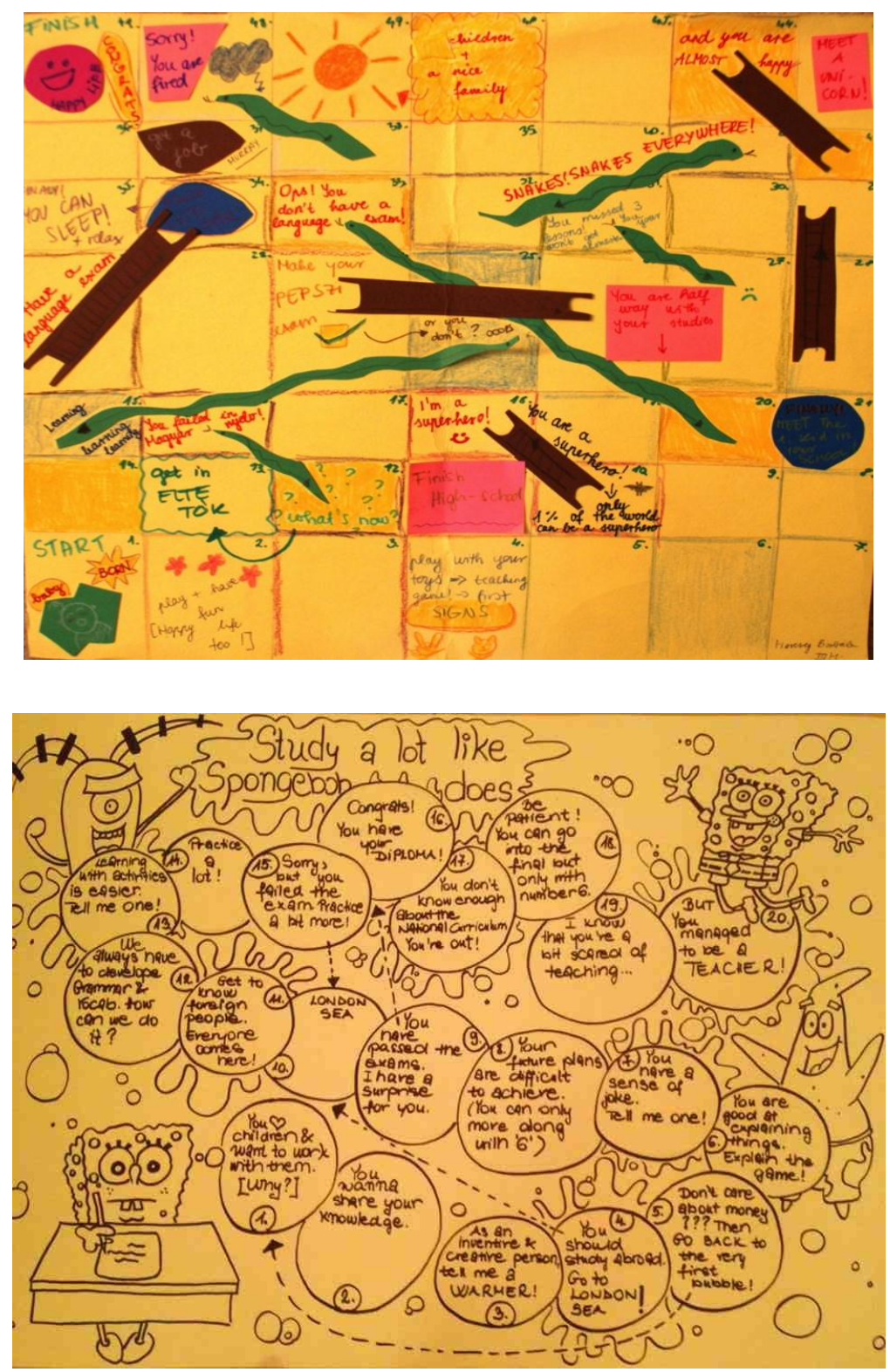

14. ábra: Kétnyelvi modult választó tanító szakos hallgatók társasjátékai eltérő stílusban (Herczeg Borbála és Fekete Erika munkái - nagyméretű társasjátékok)

Sok játéktáblához tartoznak szerencse- és/vagy feladatkártyák (lásd például 15. ábra), melyek azon túl, hogy jól tükrözik a hallgatók nézeteit, még a kétnyelvi modul során elérendő tanulási eredményekre vonatkozóan is tartalmaznak némi információt. A feladatok sikeres teljesítése vagy kudarca minden alkalommal következményekkel jár. A teljesítés elörelépést jelent, míg a nem teljesített 
feladatok visszalépést vagy lassabb haladást (kimaradást adott számú körből, kizárólag 6-os dobásával való továbbjutást) eredményeznek, esetenként pedig akár a játék teljes újrakezdését. A 4. sz. táblázatban példák láthatók az elméletibb és gyakorlatibb jellegü feladattípusokra.
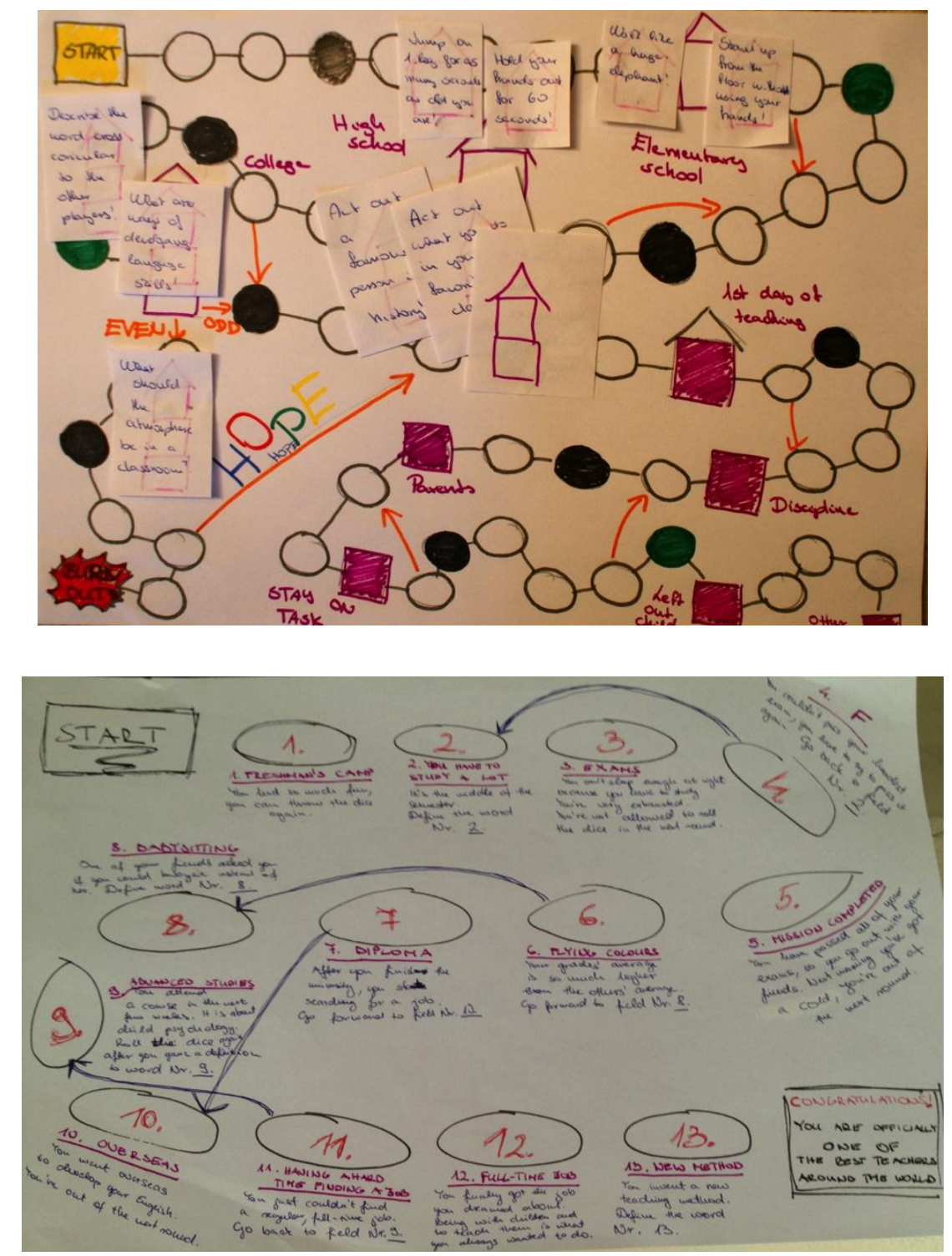

15. ábra: Tanító szakos kétnyelvi modult választó hallgatók társasjátékai feladatkártyákkal (Taylor Jennifer és Nagy Flóra munkái) 
4. sz. táblázat: Feladatkártyák (1)

\begin{tabular}{|l|l|}
\hline Elméletibb jellegü feladatok & $\begin{array}{l}\text { Gyakorlatibb, módszertani jellegü } \\
\text { feladatok }\end{array}$ \\
\hline Mi a jelentése a CLIL betüszónak? & Sorolj fel 5 angol dalt! \\
\hline $\begin{array}{l}\text { Sorolj fel 5 kompetenciát, amelyek jó } \\
\text { pedagógussá tesznek téged! }\end{array}$ & $\begin{array}{l}\text { Sorolj fel 5 bemelegítő, } \\
\text { ráhangoló/nyugtató jellegü játékot, } \\
\text { amilyen gyorsan csak tudsz! }\end{array}$ \\
\hline $\begin{array}{l}\text { Sorolj fel 5 olyan területet, amelyek a } \\
\text { második nyelv tanításával fejleszthetőek! }\end{array}$ & $\begin{array}{l}\text { Találj ki és játssz egy 3 perces játékot } \\
\text { a többiekkel! }\end{array}$ \\
\hline $\begin{array}{l}\text { Definiáld, mi a kétnyelvü oktatás- } \\
\text { nevelés! }\end{array}$ & $\begin{array}{l}\text { Melyek a nyelvi készségek } \\
\text { fejlesztésének módjai? }\end{array}$ \\
\hline $\begin{array}{l}\text { Magyarázd el, hogy mit jelent az } \\
\text {,anyanyelv”! }\end{array}$ & $\begin{array}{l}\text { Adj elö, mutass be, játssz el valamit! } \\
\text { (Pl. egy ma népszerü dalt, hogyan jár } \\
\text { egy hatalmas elefánt, hogyan kell a } \\
\text { földröl felállni kézhasználat nélkül.) }\end{array}$ \\
\hline $\begin{array}{l}\text { Magyarázd el a többieknek, hogy mit } \\
\text { jelent a tantárgyköziség stb. (megszabott } \\
\text { tiltott szavakkal)! }\end{array}$
\end{tabular}

A pedagóguskompetenciákra vonatkozó nézetek kapcsán kiemelendő az a társasjáték, ahol a feladatkártyák között tanítással kapcsolatos gondolatok is szerepelnek értelmezési feladatként. Néhány magyarra fordított idézet az alábbi, 5. sz. táblázatban olvasható az adott hallgató tanítással-tanulással kapcsolatos nézeteinek illusztrálására.

5. sz. táblázat: Feladatkártyák (2)

\begin{tabular}{|l|}
\hline \multicolumn{1}{|c|}{$\begin{array}{c}\text { Pedagóguskompetenciák megjelenése a tanítással kapcsolatos } \\
\text { gondolatokban, idézetekben }\end{array}$} \\
\hline $\begin{array}{l}\text { A középszerủ pedagógus megmond, a jó megmagyaráz, a még jobb } \\
\text { megmutat, a nagyszerú inspirál. }\end{array}$ \\
\hline $\begin{array}{l}\text { A tanulás legjobb módja a „csinálás” (to do), a tanítás legrosszabb } \\
\text { módja a „beszélés” (to talk). }\end{array}$ \\
\hline Az iskola alapvető célja a tanulás és nem a tanítás. \\
\hline A tanulás során tanítani fogsz és a tanítás során tanulni. \\
\hline $\begin{array}{l}\text { A pedagógusnak } 3 \text { szerelme van: a tanulásé, a gyerekeké és azé, hogy } \\
\text { az első két szerelmét összehozza. }\end{array}$ \\
\hline $\begin{array}{l}\text { Sose tanítom a gyerekeket, csak megpróbálok olyan körülményeket } \\
\text { biztosítani, amiben tanulni tudnak. }\end{array}$ \\
\hline $\begin{array}{l}\text { A gyerekek arra emlékeznek, hogy mi vagy és nem arra, hogy mit } \\
\text { próbálsz tanítani. }\end{array}$ \\
\hline $\begin{array}{l}\text { A tanítás tárgya az, hogy képessé tegyük a gyermeket arra, hogy } \\
\text { pedagógus nélkül is boldoguljon. }\end{array}$ \\
\hline
\end{tabular}

A hallgatók alkotásai arról is tanúskodnak, hogy sokuk számára a pályaszocializáció nem a pedagógusképző intézménybe való felvétellel kezdődik. A legtöbben ennél korábbi időpontot jelölnek meg a pályára való felkészülés kezdeteként (start mezö). Van, aki a középiskolától, de akad olyan jelölt is, aki születésének pillanatától kezdi a társasjátékkal szimbolizált folyamat leírását és gyermekkora kellemes játékélményeit. illetve a játék babák tanítgatását is szakmai 
tapasztalatként értékeli és nevezi meg. Hasonlóan, a hatékony kétnyelvi pedagógussá válás folyamata sem ér véget a diploma átvételével. A pedagógustovábbképzés, a munkahelykeresés, illetve a pályavitel kapcsán felmerülő nehézségek és veszélyek ugyanúgy fellelhetők a társasjátékmezőkben, mint a sikerességet elösegítő, támogató körülmények (lásd 6. sz. táblázat). Akár egy társasjátékon belül is megtalálható ugyanazon körülmény pozitív és negatív megközelítése (lásd 7. sz. táblázat).

6. sz. táblázat: A jó kétnyelvi pedagógussá válás társasjátéka: A segítő és gátló tényezők

\begin{tabular}{|l|l|}
\hline \multicolumn{1}{|c|}{ Tanulmányokkal kapcsolatos } & \multicolumn{1}{c|}{$\begin{array}{c}\text { Munkahellyel, pályavitellel } \\
\text { kapcsolatos }\end{array}$} \\
\hline \multicolumn{1}{|c|}{ Sikerességet segítő, előrevivő körülmények } \\
\hline sok-sok tanulás & álláskeresés \\
\hline $\begin{array}{l}\text { saját nagyszerü ötletek bizonyítása a } \\
\text { módszertan órán }\end{array}$ & a jó állás elnyerése \\
\hline $\begin{array}{l}\text { gyermekkel való találkozás (végre!) (=a } \\
\text { szakmai/tanítási gyakorlat) }\end{array}$ & $\begin{array}{l}\text { a gyerekek csinálják, részt vesznek a } \\
\text { feladatokban }\end{array}$ \\
\hline a nyelvvizsga megszerzése & a gyerekeknek tetszett az óra \\
\hline $\begin{array}{l}\text { sikeres vizsga, kiemelkedő tanulmányi } \\
\text { eredmény }\end{array}$ & gyermekfelügyelet, babysitting \\
\hline \begin{tabular}{l} 
külföldi részképzés \\
\multicolumn{2}{|c|}{ Nehézségek, akadályok, gátló-hátráltató körülmények }
\end{tabular} \\
\hline sikeres végzés, diploma megszerzése & $\begin{array}{l}\text { külföldi tanulmányút, tengerentúli } \\
\text { nyelvfejlesztés }\end{array}$ \\
\hline \multicolumn{1}{|c|}{ Tanulmányokkal kapcsolatos } & seladatból kihagyott gyermek \\
\hline \multicolumn{2}{|c|}{ fegyelmezési, magatartási problémák } \\
\hline késés angolóráról & szülök \\
\hline esszé határidőn túli beadása & munkahely elveszítése, kirúgás \\
\hline az index elveszítése & kiégés \\
\hline hiányzás miatt elveszített félév &
\end{tabular}

7. sz. táblázat: A pozitív és negatív párhuzamok a társasjátékokban

\begin{tabular}{|l|l|}
\hline \multicolumn{1}{|c|}{ Pozitív megközelítés } & \multicolumn{1}{|c|}{ Negatív megközelítés } \\
\hline $\begin{array}{l}\text { Sikeresen levizsgázol valamilyen } \\
\text { tárgyból, sikerül a szigorlatod }\end{array}$ & $\begin{array}{l}\text { Megbuksz valamilyen vizsgán, nem } \\
\text { sikerül a szigorlatod }\end{array}$ \\
\hline Van nyelvvizsgád, jól tudod a nyelvet & $\begin{array}{l}\text { Nincs nyelvvizsgád, nem tudsz jól } \\
\text { angolul }\end{array}$ \\
\hline Megkapod álmaid állását & $\begin{array}{l}\text { Hiába keresel munkát, nem találsz } \\
\text { megfelelőt }\end{array}$ \\
\cline { 2 - 2 } & Kaptál munkát, de elveszíted, kirúgnak \\
\hline
\end{tabular}

A társasjátékok egyedi megoldásai alapján megállapítható, hogy a hallgatók elképzelései változatosak, egyéniek, hiszen nemcsak a célhoz vezető út, hanem maga a cél is több esetben eltér: van, akinek az állás megszerzése, van, akinek egy saját kétnyelvü óvoda alapítása a kitüzött célja. Hasonlóan ambiciózus végállomás 
„hivatalosan is a világ egyik legjobb pedagógusává válni”; mindehhez egy új gyermek-nyelvpedagógai módszer felfedezése szükséges utolsó teljesítendő kihívásként. A kiinduló helyzet csakúgy, mint a cél érdekében megteendő lépések, az elöre, illetve visszafelé mutató folyamatok is mások esetenként. Ugyanakkor, nézeteiket, alapvető elképzeléseiket tekintve, a hallgatók teljesen egyetértenek. A szükséges sokszínü szakmai és személyes kompetenciákat illetően - kiemelten is a magas szintü nyelvtudás, módszertani és interkulturális ismeretek, a gyermekközpontúság terén - a gyakorlat szerepének hangsúlyozása mellett az elméleti jellegű tudás megszerzése is érték számukra. Az önképzés és a pedagógus(tovább)képzés fontosságának elismerése is megjelenik a társasjátékokban. A hallgatók tudatossága, kialakult nézetrendszere, a képzés során elsajátított ismeretei, elért tanulási eredményei egyértelműen, explicit módon jelennek meg a rajzos alkotásokban.

\section{Összegzés}

A hazai közoktatásban egyre nagyobb az igény szakképzett, a kétnyelvű oktatásnevelés területén kompetens pedagógusokra. Az ELTE TÓK azon kevés hazai pedagógusképző intézmények egyike, ahol a jelöltek alapképzés formájában speciális felkészítést kaphatnak a korai kétnyelvü fejlesztésre. Eddig még nem történt meg a hazai kétnyelvi pedagógusképzésben részt vevő jelöltek nézeteinek (beliefs) feltárása leendő hivatásukról, a kétnyelvüségről és a képzésről, holott a hallgatói vélekedések, a szubjektív elméletek alapvetően meghatározzák a képzés sikerét és befolyásolják a pályaszocializációt is.

A tanulmány első részében a kutatást alapozó szakirodalom ismertetése történt meg, kiemelve a nézetek pedagógusképzésben és -kutatásban meghatározó szerepét. Ezt követően kitértem a nézetek feltárására alkalmas hagyományos és új generációs kvalitatív vizsgálati módszerek bemutatására. A konkrét kutatás jellemzését, körülményeinek leírását követően a vizuális alkotások értelmezése, elemzése kapcsán szerzett tapasztalatok megfogalmazása következett a hallgatói nézetek és tanulási eredmények tekintetében.

A korai kétnyelvi alapképzésben részt vevő hallgatók nézetrendszere komplex, összetett. A többség már a képzés megkezdése elött is rendelkezik alapvető ismeretekkel (lásd Trentinné, 2013) a kétnyelvüséggel, a korai idegen nyelvi fejlesztéssel kapcsolatban. Az első szakmai modul - „A kétnyelvüség elmélete és gyakorlata" - elvégeztével tovább erősödik tudatosságuk a kisgyermekkori idegen nyelvi nevelés területén. Ennek megfelelően nézeteik, elméleti ismereteik, gyakorlati pedagógiai készségeik, szakmai attitüdjeik egyaránt megjelennek az általuk létrehozott kreatív alkotásokban. A begyüjtött, vizuális megjelenítést alkalmazó hallgatói munkák arról tanúskodnak, hogy a hallgatók már a kétnyelvi képzés korai szakaszában is rendelkeznek nézetekkel arra vonatkozóan, hogy milyen kompetenciákra van szüksége egy korai kétnyelvü programban tevékenykedő pedagógusnak. Arról is határozott elképzelésük van, hogy milyen lépéseket kell tenniük annak érdekében, hogy a végzést követően belölük is jó kétnyelvi pedagógus váljon. Jellemző rájuk többek között a 
gyermekközpontúság, a módszertani tudatosság, a kreativitás, a két-, illetve többnyelvüség, valamint a multikulturalitás értékeinek elismerése. Fontos számukra az élethosszig tartó tanulás, a nyitottság, a szakmai rátermettség, a magas szintű nyelvtudás, valamint a hivatástudat.

Az ideális kétnyelvi pedagógusról készített kreatív, rajzos alkotások és a kétnyelvi pedagógussá válás folyamatát bemutató társasjátékok elemzésének tapasztalatai megegyeznek a mese- és metaforavizsgálatok fontosabb eredményeivel, igazolva az alkalmazott kutatási technika megbízhatóságát. A fentiek alapján kijelenthető, hogy a vizuális hallgatói alkotások vizsgálata jó lehetőséget teremt a pedagógusjelöltek nézeteinek, személyes filozófiájának megismerésére, és kimondottan alkalmas pedagógusképzési és kutatási célok megvalósítására egyaránt.

\section{Jegyzetek}

Bárdossy Ildikó - Dudás Margit (2011): Pedagógiai nézetek. Tanári mesterképzést bevezetö tanulási/tanitási program oktatók és hallgatók számára. Pécsi Tudományegyetem, Pécs.

Calderhead, J. (1996). Teachers: Beliefs and Knowledge. In: Berliner, D. és Calfee, R. (ed.). Handbook of Educational Psychology. MacMillan, New York 709-725.

Demeter Katalin - Szarka Júlia (szerk. 2011): NÓK-tanterv. Tájékoztató jegyzet, 2011. július 1. óvodapedagógus hallgatóknak a képzésröl. ELTE TÓK, Budapest.

Dudás Margit (2005): A tanárképzésbe belépő hallgatók nézeteinek feltárási lehetőségei. In: Pedagógusképzés, 2005. 3. 23-43.

Dudás Margit (2007): Tanárjelöltek belépő nézeteinek feltárása. In: Falus I. (szerk): A tanárrá válás folyamata. Gondolat Kiadó, Budapest.

Ehmann Bea (2002): A szöveg mélyén. Új Mandátum Kiadó, Budapest.

Falus Iván (szerk. 1998): Didaktika. Elméleti alapok a tanitás tanulásához. Nemzeti Tankönyvkiadó, Budapest.

Falus Iván (2001a): Pedagógus mesterség - pedagógiai tudás. In: Iskolakultúra, 2. 21-28.

Falus Iván (2001b): Gondolkodás és cselekvés a pedagógus tevékenységében. In: Báthory Z. - Falus I. (szerk.): Tanulmányok a neveléstudomány köréböl. Osiris Kiadó, Budapest.

Falus Iván (2002): A pedagógusképzés modelljei az Európai Közösség országaiban. In: Bábosik I. - Kárpáti A. (szerk.): Összehasonlitó pedagógia. BIP, Budapest.

Falus Iván (2006a): A tanári tevékenység és a pedagógusképzés új útjai. Gondolat Kiadó, Budapest.

Falus Iván (2006b): Tanári képesítési követelmények - kompetenciák - sztenderdek. In: Demeter Kinga (szerk.): A kompetencia. Kihívások és értelmezések. Országos Közoktatási Intézet, Budapest. 299-309.

Falus Iván (szerk. 2007): A tanárrá válás folyamata. Gondolat Kiadó, Budapest.

Falus Iván, Golnhofer Erzsébet, Kotschy Beáta, M. Nádasi Mária, Szokolszky Ágnes (1989): A pedagógia és a pedagógusok. Egy empirikus vizsgálat eredményei. Akadémiai Kiadó, Budapest.

Golnhofer Erzsébet (2001): Pedagógusok nézetei a gyerekekröl, a diákokról. In: Golnhofer Erzsébet - Nahalka István (szerk.): A pedagógusok pedagógiája. Nemzeti Tankönyvkiadó, Budapest. 
Golnhofer Erzsébet - M. Nádasi Mária (1981): Tanárjelöltek a nevelés céljáról. In: Magyar Pedagógia, 3. 305-310.

Hunyady Györgyné (2001): Laikus pedagógiai nézetek vizsgálata. In: Tanulmánykötet. NyME Apáczai Csere János Tanítóképző Főiskolai Kar. 62-71.

Hunyady Györgyné (2004): Laikus pedagógiai tapasztalatok és nézetek vizsgálata a tanítójelöltek körében. In: Bollókné Panyik I. (szerk.): Gyermek - nevelés pedagógusképzés. Az ELTE TÓFK Tudományos Közleményei, XXVII. Trezor Kiadó, Budapest. 9-33.

Hunyady Györgyné (2006): Pedagogikum a szépirodalomban. In: M. Nádasi M. (szerk.): A gyakorlati pedagógia néhány alapkérdése: pedagogikum a hétköznapokban és a müvészetekben. Bölcsész Konzorcium, Budapest. 15-36.

Hunyady Györgyné - Ungárné Komoly Judit (1999): Pedagógusjelöltek nevelési attitüdjeinek vizsgálata irodalmi szemelvények segítségével. In: Bollókné Panyik I. (szerk.): Gyermek - nevelés - pedagógusképzés. Trezor Kiadó, Budapest. 7-38.

Hunyady Györgyné (1993): Szépirodalom és pedagógia. In: Új Pedagógiai Szemle, 43. 7-8. sz. 107-114.

Kimmel Magdolna (2007): A tanárképzés problémái konstruktivista értelmezési keretben. In: Falus Iván (szerk.): A tanárrá válás folyamata. Gondolat Kiadó, Budapest.

Korthagen, F. A. J. (1993). Two modes of reflection. Teaching and Teacher Education, (9) 3, 317-326.

Kovács Judit (2008): Innováció a kéttannyelvüségben: a párban történő magyar-angol általános iskolai program vizsgálata. In: Vámos Á. - Kovács J. (szerk.): A két tanítási nyelvü oktatás elmélete és gyakorlata 2008-ban. Jubileumi tanulmánykötet. Eötvös József Könyviadó, Budapest. 187-212.

Kovács Judit (2009): Magyar-angol kéttannyelvü tanító- és óvópedagógus-képzés az ELTE Tanító- és Óvóképző Főiskolai Karán. In: Kovács Judit és Márkus Éva (szerk.): Kéttannyelvüség - pedagógusképzés, kutatás, oktatás. ELTE Eötvös Kiadó, Budapest. $42-52$.

Kovács Judit - Trentinné Benkő Éva (2010): Hitek és tévhitek. Idegennyelvi fejlesztés az óvodában. In: Óvónők Kincsestára, E 3.7. 1-24

Kovács Judit - Molnárné Lipták E. (2003): Ahol az élet két nyelven folyik. In: Óvodai nevelés, 7. 286-288.

Kovács Judit (2006): Magyar-angol kéttannyelvü általános iskolai programok közoktatásunkban. Eötvös József Kiadó, Budapest.

Köcséné Szabó Ildikó (2007): Milyen tanár leszek? - hallgatók vallanak magukról, a tanári hivatásról. In: Falus I. (szerk.): A tanárrá válás folyamata. Gondolat Kiadó, Budapest.

Kramsch, C. (1994). Context and Culture in Language Teaching. Oxford University Press: Oxford.

Laidlaw, C. (2001). Intercultural Learning. A Resource Book for Primary Teachers of English. Nemzeti Tankönyvkiadó, Budapest.

Lortie, D. (1975). Schoolteacher: A sociological study. University of Chicago Press: Chicago.

M. Nádasi Mária (1999): Hétköznapi és/vagy tudományos pedagógia? Tanári létkérdések. Raabe Kiadó, Budapest.

M. Nádasi Mária (2001): A pedagógus pálya foglalkozási ártalmai - pályakezdők közérzete. In: Radnainé Szendrei J. (szerk.): Ezredforduló, müveltségkép, kisgyermekkori nevelés. Trezor Kiadó, Budapest. 70-74. 
M. Nádasi Mária (2002): Az oktatáselméletek hatás(talanság)a a gyakorlatra. In: Bábosik I. - Kárpáti A. (szerk.): Összehasonlító pedagógia. Books in Print Kiadó, Budapest.

M. Nádasi Mária (2006): Pedagogikum a hétköznapokban. In: M. Nádasi M. (szerk.): $A$ gyakorlati pedagógia néhány alapkérdése: Pedagogikum a hétköznapokban és a müvészetekben. Bölcsész Konzorcium, Budapest. 4-14.

Mason, J. (2005): Kvalitatív kutatás. Jószöveg Kiadó, Budapest.

Morvai Edit - Poór Zoltán (2006): Korai nyelvoktatás a magyar oktatási intézményekben. www.nefmi.gov.hu/download.php?docID=732 (elérhető: 2013. január 25.)

Nahalka István (2003a): A nevelési nézetek kutatása. In: Iskolakultúra, 5. sz. 69-75.

Nahalka István: Az oktatás tartalma. In: Falus Iván (szerk. 2003b): Didaktika. Elméleti alapok a tanitás tanulásához. Nemzeti Tankönyvkiadó, Budapest.

OECD (2005). Teachers Matter. Attracting, Developing and Retaining Effective Teachers. Education and Training Policy. OECD Publishing: Paris.

OECD (2008). Teaching and Learning International Survey (TALIS). www.oecd.org/TALIS (elérhető 2013. január 25.)

Pajares, F. (1992). Teachers' beliefs and educational research: Cleaning up a messy construct. In: Review of Educational Research. 62(3), 307-332.

Poór Zoltán (2012): Opponensi vélemény Trentinné Benkő Éva: Pedagóguskompetenciák, pedagógusképzés és a korai kétnyelvü fejlesztés doktori értekezésének mühelyvitájára.

Richardson, V. (1996). The role of attitudes and beliefs in learning to teach. In: Sikula, J. (ed.). Handbook of Research on Teacher Education. Macmillan: New York (2nd ed. 102-119).

Sántha Kálmán (2004): A pedagógusok reflektív gondolkodásának vizsgálata. In: Pedagógusképzés, 2. sz. 27-44.

Sántha Kálmán (2006): Mintavétel a kvalitativ pedagógiai kutatásban. Kutatásmódszertani kiskönyvtár, Gondolat Kiadó, Budapest.

Seidman, I. (2002): Az interjú, mint kvalitativ kutatási módszer. Kutatás-módszertani kiskönyvtár, Müszaki Könyvkiadó, Budapest.

Szabolcs Éva (1999): A kvalitatív kutatási módszerek megjelenése a pedagógiában. In: Magyar Pedagógia, 3. sz. 343-348.

Szabolcs Éva (2001): Kvalitatív kutatási metodológia a pedagógiában. Müszaki Könyvkiadó, Budapest.

Szivák Judit (2002): A pedagógusok gondolkodásának kutatási módszerei. Műszaki Könyvkiadó, Budapest.

Szivák Judit (2003a): A reflektív gondolkodás fejlesztése. Gondolat Kiadói Kör, ELTE BTK Neveléstudományi Intézet, Budapest.

Szivák Judit (2003b): Hallgatók neveléssel kapcsolatos nézetei. In: Iskolakultúra. 5. 8895.

Tárnok Péter (2009): Kompetencia alapú nyelvelsajátítás óvodákban. In: Kovács J. Márkus É. (szerk.): Kéttannyelvűség - pedagógusképzés, kutatás, oktatás. ELTE Eötvös Kiadó, Budapest. 101-104.

Tolnai Katalin (2009): Félúton - A természetes és a mesterséges között (A HABAKUKK Alapítványi Óvoda Európai Nyelvi Díjjal kitüntetett „Szelíd nyelvi nevelés” címü programjának bemutatása). In: Kovács J. - Márkus É. (szerk.): Kéttannyelvüség pedagógusképzés, kutatás, oktatás. ELTE Eötvös Kiadó, Budapest. 
Trentinné Benkő Éva (2008): Az „ideális” kéttannyelvű tanár - ahogy a pedagógusok látják. In: Vámos Á. - Kovács J. (szerk.): A két tanitási nyelvü oktatás elmélete és gyakorlata 2008-ban. Jubileumi tanulmánykötet. Eötvös József Könyvkiadó, Budapest. 248-264.

Trentinné Benkő Éva (2009): Az „ideális” kéttannyelvü tanár - ahogy a pedagógusok látják. In: Kovács, J. - Márkus, É. (szerk.): Kéttannyelvüség - pedagógusképzés, kutatás, oktatás. ELTE Eötvös Kiadó, Budapest. 143-158.

Trentinné Benkő Éva (2013): A kétnyelvi pedagógusképzésbe belépő hallgatók nézetei és motivációi. In: Márkus É. - Árva V. (szerk.): Az ELTE TÓK Idegen Nyelvi és Irodalmi Tanszékének Tudományos Közleményei (megjelenés alatt). ELTE TÓK, Budapest.

Vámos Ágnes (2001a): Iskolai értékelés fogalmának elemzése metaforahálóval. In: Golnhofer E. - Nahalka I. (szerk.): A pedagógusok pedagógiája. Nemzeti Tankönyvkiadó, Budapest.

Vámos Ágnes (2001b): Metafora felhasználása a pedagógiai fogalmak tartalmának vizsgálatában. In: Magyar Pedagógia, 1. 85-114.

Vámos Ágnes (2003a): Metafora a pedagógiában. Gondolat Kiadói Kör, ELTE BTK Neveléstudományi Intézet, Budapest.

Vámos Ágnes (2003b): Metafora a pedagógiai kutatásban. In: Iskolakultúra, 4. 109-112.

Vámos Ágnes (2008): A kezdő tanár mint hős: a mese és pedagógiai felhasználása. In: Iskolakultúra, 1-2. 24-38.

Vámos Ágnes - Kovács Judit (szerk. 2008): A két tanitási nyelvü oktatás elmélete és gyakorlata 2008-ban. Jubileumi tanulmánykötet. Eötvös József Könyvkiadó, Budapest.

Vass Vilmos (2006a): A kompetencia fogalmának értelmezése. In: Demeter K. (szerk.): A kompetencia. Országos Közoktatási Intézet, Budapest. 139-161.

Vass Vilmos (2006b): A kompetencia fogalmának értelmezése. In: Kerber Z. (szerk.): Hidak a tantárgyak között. Országos Közoktatási Intézet, Budapest.

Wubbels, T. (1992). Taking account of student teachers' preconceptions. In: Teaching and Teacher Education, 8 (2), 137-149.

\section{Függelék}

1. sz. melléklet

Az ideális kétnyelvü óvodapedagógus rajzának elemzése a hallgató/alkotó által (Szabó Tímea, NÓK 2011. I. évf. 2. csoport)

Ceruzarajz, melynél élénk, de nem túl erős színeket használtam, ezzel jelenítve meg a gyermeki látásmód játékosságát. A részletgazdagság nem jellemző a képre, csupán az előtérben lévő alakokra fektettem hangsúlyt. Így érzékeli egy gyermek is a világot, megragadja a lényeget, a színek és formák kontrasztját, $\mathrm{s}$ így is ugyanannyira felismerhetőek és elkülöníthetőek a fontosabb dolgok.

A kép középpontjában egy fiatal nőalak foglal helyet törökülésben. Az előtérben óvodás korú gyermekek ülnek vele szemben, a háttérben pedig hegyes-völgyes vidék látszik, felette a kék ég. A környezet szimbolizálja azt a természetességet, amely tulajdonsággal egy kétnyelvü óvodapedagógusnak rendelkeznie kell, hiszen neki olyan nonverbális nyelvet is beszélnie kell, ami időtlen, s nem kell az érzékszerveinkre hagyatkozni annak megértéséhez. Továbbá leképezi azt az egymásrautaltságot, amit sokan elfelejtenek: ugyan a természet összhangjában is vannak alá- és fölérendelt viszonyok, mégsem képes egymás nélkül tökéletesen müködni egy organizmus sem. 
Igaz, hogy többnyire az óvodapedagógus feladata egyengetni a kisgyermek útját, nekünk mégsem kell elzárkózni attól, hogy mi is tanuljunk az apróságoktól, hisz rengeteget segíthetnek saját magunk megismerésében.

A magas égbolt a határtalan lehetöségeket jelzi, amely felé törekszünk, bár meg kell mászni számos hegyet, erőfeszítést kell tenni újra és újra a változás érdekében, s nem törődni bele a megoldhatatlannak tủnő helyzetekbe. Az óvodapedagógus jobbján elhelyezkedő fa is a szerves egységet, a növekvést és a bölcsességet fejezi ki. Egy fa lassan növekszik, de csemete korában még van mód rá, hogy formálódjon. Én személy szerint nem hiszek abban, hogy egy-egy ember képes egy gyermeket megváltoztatni, nem hiszem, hogy születésünkkor egyformák vagyunk, hogy minden csak nevelés kérdése. Abban hiszek, hogy mindenki teljesen más tulajdonságokkal és érzelmi adottságokkal jön a világra, s nekünk, pedagógusoknak ehhez mérten kell alakítani a gyermek jellemét, ehhez mérten kell vele kommunikálnunk. Nincs értelme a fa köré betont önteni, hisz a gyökerei felrepesztik az aszfaltot. Lombkoronája viszont éltető, alapvető szükségletünk kielégítéséhez juttat hozzá, a levegővételhez, az Élet befogadásához.

A háromszög alakban elrendezett előtér kompozíciója harmonikusságot kelt, s a tekintetünket a középpontban ülő női alakra szegezi. Ruhája nőies - bő szoknyája mellett mindenki talál menedéket. Meghallgatja a bánatot, a sírást, majd megoldást kínál a gyermeknek, és igyekszik őt rávezetni a megoldás megtalálására és a helyzet feloldására. Természetesen ez kitartást igényel, sokszor nap, nap után ugyanazokkal a problémákkal szembesül egy (kétnyelvü) óvodapedagógus, akár nyelvtanulás, akár az érzelemvilág terén. A ruha jobb oldalán NagyBritannia zászlajának mintája, a balon pedig Magyarországé látszik. A két zászló színei közül a pirosak összeolvadnak, színátmenetet képez a szoknya redőzete. Ez egyértelműen arra mutat, hogy milyen játékosan és határok nélkül lehet tanulni/tanítani idegen és anyanyelvet óvodás korban. Az alak bal kezét az ölében nyugtatja, jobb kezével gesztikulálva energiát csoportosít, mondhatnánk úgy, varázsol. Cikázó fényfoltokat, amelyek meséjét elevenítik meg. Ezzel célom a gyermeki tudat leképezése volt, már amennyire a saját emlékeim és benyomásaim ezt lehetővé tették. Az alak arca és teste nyugalmat áraszt. Olyan embert tükröz, aki békés, játékos, jó a (meta)kommunikációs képessége, tehát képes arra, hogy magára irányítsa a figyelmet, amikor arra szükség van, és higgadtan és körültekintően tudja kezelni a felmerülő problémákat. A képen a kisgyerekek szemben az óvodapedagógussal ülnek vagy fekszenek. Igyekeztem érzékeltetni a különböző etnikumú gyerekek összetételét, ezzel utalva a kétnyelvűségre. Mindannyian figyelnek a mesére, amit az óvónő fejből mond el. Nagyon fontos ez ahhoz, hogy hiteles legyen a mese, mert így van (szem)kontaktus a mesélö és a hallgatóság között.

Továbbá a mindennapi életben is épp ilyen rendszeres kapcsolatnak kell lennie az óvodapedagógus és a gyermekek között, úgy értem belső kapcsolat, amely abból áll, hogy a csoportunkba járó $\mathrm{X}$ gyermekért félig most mi vagyunk a felelősek. Ránk bízták őket, s mi, pedagógusok azért vagyunk a pályán, hogy segítsünk felnőni egy tudatosabb, szabadabb, kreatívabb generációnak."

\section{2. sz. melléklet}

\section{Az ideális kétnyelvủ óvodapedagógus rajzának elemzése a hallgató/alkotó által (Novák Doroti, NÓK 2011. I. évf. 2. csoport)}

\section{Hogy miért is lett egy pók az én óvodapedagógusom?}

Ez pofonegyszerü! Saját magamból kiindulva a fantáziámra bíztam az ideális óvónő megszemélyesítését. Jellegzetességemet belevíve a feladatba, kissé megspékeltem a munkámat. Miért is kéne egy emberalakot öltött pedagógust lerajzolnom? Nem kell! Épp ezért egy pókot képzeltem el, melynek emberi felsőteste van, de ugyanakkor megtartja a pók jellemző jegyeit. Gondolok itt például a több szempárra, a nagy potrohra és természetesen a 8 lábra is. Számomra egy tökéletes óvodapedagógusnak nagyon fürgének kell lennie, de ugyanakkor észrevétlennek is. 
Mindent át kell látnia, de úgy, hogy ezzel ne zavarja meg a gyerekek tevékenységeit. Össze kell tartania a gyerekeket, de az ne legyen egy kötelező feladat számukra, hanem inkább egy kellemes játék.

Sorra vettem a számomra fontos elemeket, amelyeket az óvodapedagógusnak tudnia kell ahhoz, hogy igazán megfelelő példaértéket tudjon felmutatni. A pók formájában igazán könnyedén el tudtam képzelni ezt a csodás pedagógust. Több szem többet lát alapon gondoltam arra, hogy ezzel sokkal több mindenre tudna figyelni. Bármilyen helyzetben átlátná a problémákat, ha felmerülnek. A 8 láb is felettébb hasznosnak mondható, mivel ha baj van, hamarabb a helyszínre siethet a pedagógus, de nem csak ezt tartom pozitívnak, hanem azt, hogy bármerre képes közlekedni: a falon, a plafonon, és bármely szemszögböl képes ez a "lény" figyelmét a gyerekeknek szentelni.

A pókfonál is felmerült bennem mint fontos elem, hiszen azzal összetarthatja a gyerekeket vagy a helyes irányba terelheti öket észrevétlenül. Végül, de nem utolsósorban ez a fantáziából megalkotott lény kétnyelvü is egyben. Ez azt jelenti, hogy angolul is kiválóan kommunikál, ezzel segítve a gyerekek kétnyelvűségét. A háttérben egy pókhálót rajzoltam, ahol szemléltetni tudtam még jobban a pedagógus sokoldalúságát. Több fejlesztési területet is érintenek a megrajzolt játékok, eszközök, illetve játékformákra is utalnak. Köztük van, amely utal a szerepjátékra, míg egy másik a szabályjátékra. De találhatunk példát zenei, irodalmi vagy vizuális tevékenységre utaló eszközre is. Az altatáshoz is készítettem egy altató plüssfigurát. Amiket a póklény lábainál láthatunk, azok kinti jellegzetességre, illetve az óvodapedagógusunk egyéb tulajdonságaira utalnak. Megjelennek a kinti játékok, a vödör és a lapát formájában. A béke és a szeretet szimbólumát szerintem nem is kell magyaráznom, ehhez hozzá tartozik a türelem, a megértés és még sok belső tulajdonság is.

Végül pár szóban szeretném összefoglalni pontosan, hogy valójában miért is választottam ezt a formát a feladat megvalósításához: Ha szemügyre vesszük a rajzom, igazán nem titok, hogy kissé félelmetesre sikerült a pedagógusom. DE! Ezzel is azt szerettem volna ábrázolni, hogy nem igazán a külső a lényeg, hiszen bárhogyan nézhet ki egy pedagógus, ha meleg szíve van, és ha jól végzi a feladatát. Ha jól belegondoltok, könnyen megérthető a választásom! A pók is egyfajta óvodapedagógus, nem? Rengeteg kicsinye kel ki, akiket a hátán hordoz, nevel és véd. Az állatvilágban is megtalálhatjuk a óvodapedagógusokat!

"A csodát meglátod, ha kinyitod a szemed, a szeretetet megérzed, ha kinyitod a szíved! Novák Dorothy"

\section{3. sz. melléklet}

\section{A jó kétnyelvi tanító fényképéhez füzött magyar nyelvű magyarázatok (Taylor Jennifer)}

1. Legyen sok új kreatív ötlete, ami motiválja a tanulókat, és ezáltal segíti eredményes tanulásukat.

2. Nem elsődleges szempont, de nem elhanyagolható, hogy legyen elegáns, divatos a megjelenése, ami szintén példaként állhat a gyerekek előtt.

3. Ha valaki egy tanítóra gondol, mindig elképzel valamilyen tárgyat, dolgot, ami más embernél nem lehet, csak egy gyerekekkel foglalkozó embernél. Legyen ez pecsételő, magatartáskártya vagy valami más által kidobott holmi, de egy tanítónál biztosan van valami ilyesmi.

4. Legyen nála egy tükör, hogy mindig tudjon reflektálni saját magára. Persze a gyerekek nagyon fontosak, de sokszor elfelejtenek magukra nézni a pedagógusok, és ettől vagy kiégnek, mert nem veszik észre saját szükségleteiket, vagy elhanyagolják munkájukat, mert azt gondolják, hogyha valami nem sikerült jól, az csak a gyerekek hibája lehet.

5. Nagyon fontos, hogy egyénekként kezelje a gyerekeket, és mindenkihez megtalálja az utat, ha nem is egy kézzel fogható kulccsal, de az idejével, energiájával; oda kell figyelnie minden gyerek szükségletére. 
6. Bárhová megy, mindig gyüjti az ötleteket, és ezért van nála mindig egy nagy táska.

7. Sokan azt gondolják, hogy egy pedagógusnak mindent tudnia kell, de ez lehetetlen, pláne a mai, napról napra változó világban, ezért nem szabad félnie azt mondani, hogy ezt nem tudom, hanem ki kell mondania és meg kell néznie, adott esetben, egy nagy könyvben a választ.

8. Integrálja a különböző tantárgyakat, ahogyan tudja, kreatívan, hiszen sok összefüggés van a tantárgyak között.

9. Van nála egy titokzatos doboz, ami mindig felkelti a gyerekek érdeklődését. Kell lenni az ember tarsolyában valami meglepőnek, ha esetleg lankadna a figyelem, vagy éppen nem úgy fogadják a tananyagot, vagy csak nincsenek megfelelő állapotban. Ilyenkor jól jön egy kis szünet, valami más, egy kis izgalom.

10. A legfontosabb, hogy a gyerekekre tekint, és őket tartja a legfontosabbnak.

11. Mindig van nála valamilyen játék. Nem feltétlen fejlesztő játék, de valamilyen játék, mert az a gyerekek alaptevékenysége, abban lehetnek önmaguk, abban lelik örömüket.

12. Megérti, hogy a gyerekeknek mire van szükségük, az adott órán és általában, és ahhoz igazítja az órai tevékenységeket.

13. Valamiért mindig csupa színben ábrázolják a tanítókat, talán mert egyéniségüket tükrözi, vagy mert rengeteg szemléltető eszközzel rendelkeznek, amik segítik munkájukat.

14. Mindig van nála egy jó gyermekkönyv. Angoltanárként Dr. Seuss elengedhetetlen, de bármilyen könyvvel közelebb viheti a gyerekeket az olvasók világába, bármivel fejlesztheti személyiségüket.

15. Nem fél lehajolni a gyerekekhez, nem fél attól, hogy az ő szintjükön legyen, esetleg játsszon velük. Szerintem úgy válik valaki igazán jó pedagógussá, ha ő maga is egy kicsit gyerek marad. 